\title{
IBN AL-ṢID AL-BAṬALYAWSĪ (444/1052-521/1127): DE LOS REINOS DE TAIFAS A LA ÉPOCA ALMORÁVIDE A TRAVÉS DE LA BIOGRAFÍA DE UN ULEMA POLIFACÉTICO ${ }^{1}$
}

\author{
DELFINA SERRANO \\ CSIC Madrid
}

La trayectoria vital del ulema andalusí Ibn al-Sīd al-Bațalyawsī se extiende, a través del tiempo, entre las épocas de los reinos de taifas y del imperio almorávide, conduciéndonos, a través del espacio, a distintas regiones del territorio andalusí. Sus horizontes intelectuales fueron amplios: gramático, lexicógrafo, literato y tradicionista, también se interesó por cuestiones jurídicas, teológicas y filosóficas. Su aportación a todos estos campos ha sido valorada positivamente dentro de la cultura islámica, gozando asimismo del aprecio de investigadores occidentales, sobre todo por lo que se refiere a su labor gramatical y a sus «escarceos» filosóficos.

El análisis de la biografía de Ibn al-Sīd ${ }^{2}$ no es fácil; en contraste con el elevado número de las obras por él compuestas que han llegado a nuestras manos, la información conservada sobre su vida es muy escasa. El de Ibn al-Sīd no es un caso aislado, pues la misma escasez de datos se repite con otros muchos pensadores, escritores prolíficos y maestros reconocidos de la cultura de al-Andalus. No por ello deja de ser cierto que cualquier análisis de la obra de un personaje quedará descompensado si dejamos de lado su biografía o desaprovechamos las posibilidades de que disponemos para conocerla. Al estudiar el

\footnotetext{
${ }^{1}$ Este trabajo se ha llevado a cabo durante mi estancia en el Orientalisches Seminar de la Universidad de Friburgo (Alemania), gracias a una beca posdoctoral concedida por el Ministerio de Educación y Cultura y a la acogida de U. Rebstock.

Las observaciones de $\mathrm{M}$. Fierro a versiones anteriores de este artículo me han hecho replantearme una parte considerable del mismo. Agradezco también las numerosas sugerencias de M. Marín y S. Stroumsa y los comentarios de los miembros del consejo de redacción de la revista Al-Qanțara. Quiero dar las gracias asimismo a M.J. Viguera y A. Zomeño.

${ }^{2}$ Los estudios que abordan con mayor profundidad su vida son la tesis inédita de M. Amīn y el trabajo de Ș. Abū Ŷanāḥ que cito en n. 4, pero que no he podido consultar.

Al-Qanțara XXIII, 1 (2002) 53-92
} 
Kitāb al-tanbih, obra que Ibn al-Sīd de Badajoz compuso sobre las causas de la discrepancia en el credo y la doctrina islámicas, me pareció que era imprescindible llenar el vacío existente sobre su biografía. El análisis de la trayectoria vital de Ibn al-Sīd puede ayudarnos, además, a comprender mejor cuestiones tales como los mecanismos de adaptación de los ulemas a las cambiantes circunstancias políticas, la relación entre las disciplinas intelectuales y las sociedades en las que se desarrollan y cómo se produce y se logra mantener la imbricación entre ciencias profanas y religiosas.

La semblanza más extensa que se conserva sobre Abũ Muhammad ${ }^{\mathrm{c}} \mathrm{Abd}$ Allāh Ibn al-Sīd al-Bațalyawsī es la que le dedica al-Fatḥ b. Jāqān. Este texto, transmitido íntegramente por al-Maqqarī en $A z \dot{h} \bar{a} r$ al-riyāe , está redactado en una rebuscada prosa rimada ${ }^{3}$ y abunda en ripios y generalizaciones. No obstante, creo haber obtenido un considerable provecho de esta fuente, en especial por lo que se refiere a la cronología de los desplazamientos de nuestro personaje. Por otra parte, los biógrafos ignoran tanto los orígenes del interés de Ibn al-Sīd por la filosofía como sus resultados. Es ésta una cuestión en la que merece la pena detenerse, ya que ese interés ha sido visto como un preludio del florecimiento filosófico que tendrá lugar durante las épocas almorávide y almohade con Avempace, Ibn Tufayl y Averroes.

\section{Orígenes y nacimiento de Ibn al-Sīd: Silves $\mathbf{y}$ Badajoz $^{4}$}

La cadena onomástica de Ibn al-Sīd carece de referencias a su filiación étnica y a posibles lazos de clientela. Ibn Jallikān considera

\footnotetext{
${ }^{3}$ Muestra sin duda del preciosismo que se impone en la prosa literaria andalusí a partir del siglo $\mathrm{V} / \mathrm{X}$ y que se consolida en el siglo siguiente, constituyendo Ibn Jāqān uno de sus principales representantes. Véase Garulo, T., «La literatura» en Viguera, M.J., et al., Los reinos de Taifas. Al-Andalus en el siglo XI, HEM, VIII-1, Madrid, 1994, 630-1.

${ }_{4}$ Sobre la vida y la obra de Ibn al-Sīd, véase: 1) Fuentes primarias: Ibn Bassām, Dajīira (ed. I. 'Abbās), Beirut, 1979, III, 890-6; Ibn Jāqān, apud al-Maqqarī, Azhār

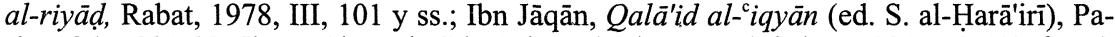
rís, 1861, 221-32; Ibn Baškuwāl, Șila (ed. I. al-Abyārī), El Cairo, 1989, n. ${ }^{\circ}$ 649; ' 'Iyāḍ, Gunya (ed. M. Ŷarrār), Beirut, 1982, 158-9 n. ${ }^{\circ} 61$; Ibn Dihya, al-Mutrib, El Cairo, 1954, 225 y ss.; al-Dabbī, Bugya (ed. I. al-Abyārī), El Cairo, 1989, n. ${ }^{\circ} 895$; al-Dahabī, Siyar, Beirut, 1986, XIX, 532-3 n. ${ }^{\circ}$ 315; Ibn Farḥūn, Dïbāây (ed. M.A. Abū 1-Nūr), El Cairo, 1972, I, 441; Ibn Sa īd, al-Mugrib (ed. Š. Ḍayf), El Cairo, 1953, I, 385; Ibn al-Ŷazarī, Gāyat al-nihāya (ed. G. Bergsträsser y O. Pretzl), Bagdad, 1932, I, 449 n. ${ }^{\circ} 1873$; al-Qiftī, Inbāh al-ruwāt (ed. M.A.F. Ibrāhīm), El Cairo, 1952, II, 141-3; al-Șafadī, al-Wāfi
} 
conveniente señalar que sid es uno de los sinónimos de $\underline{\text { ditb (lobo; }}$ adive) que se emplean también como nombres de persona ${ }^{5}$. En la onomástica andalusí el término aparece con relativa frecuencia, a veces confundido con Sayyid. En su acepción de «león», sidd era un título que solía aplicarse a determinados jefes militares ${ }^{6}$. Podríamos encontrarnos ante una conversión relativamente tardía al Islam por parte de la familia o ante un linaje en el que, como en tantos otros casos ${ }^{7}$, la relevancia social se adquiere al prestar servicios militares al poder is-

bi-l-wafayāt (ed. H. Ritter et al.), Wiesbaden, 1962, XVII, n. ${ }^{\circ}$ 478; al-Suyūṭī, Bugyat $a l$-wu $u^{c} \bar{t}$ (ed. M.A. Ibrähīm), El Cairo, 1964, II, 55 n. ${ }^{0} 1422$; al-Maqqarī, Nafh al-țīb (ed. A.Y. Naŷātī), El Cairo, 1936, V, 265-98 y (ed. R. Dozy et al.) Amsterdam, 1967, I, 113; Ibn Jallikān, Wafayāt al-a $a^{c} y a ̄ n$ (ed. I. 'Abbās), Beirut, 1968-77, III, 96.

2) Fuentes secundarias: Ibn al-' Imād, Sadarāt al-dahab, Beirut, 1979, IV, 64; ${ }^{\circ} \mathrm{A}$. al-Q. al-Bagdādī, Jizānat al-adab, Beirut (reimpr. El Cairo, 1299/1882), III, 27 y 170; I.B. al-Bagdādī, Hadiyyat al- ${ }^{c}$ ärifín (Estambul, 1955), I, 454; Ibn Kațīr, al-Bidāya wa-l-nihāya, El Cairo, s.d., XII, 198.

3) Bibliografia: Haŷŷî Jalīfa, Kašf al-zunūn Leipzig, 1835-52, I, 222, 266, 458, II, 430, 624, 626, III, 311, 601, IV, 320, 444, V, 74, 374, VI, 265 y VII, 683, 700, 733; Kahhāla, 'U.R., Mu'ŷam al-mu'allifin, Damasco, 1957-61, VI, 121-2; Majlüf, M., Šaýarat al-nūr, El Cairo, 1950-2, I, 130; Ziriklī, J.D., al-A läm, Beirut, 1980-86, III, 101; Codera, F., Decadencia y desaparición de los almorávides en España, Zaragoza, 1899, 347-53; Brockelmann, C., GAL, I, 427, SI, 758; $E I^{2}$ s.v. «al-Batalyawsì» [Lévi-Provencal, E.]; Asín Palacios, M., «Ibn al-Sìd de Badajoz y su «Libro de los cercos» (Kitāb al-ḥadā'iq»)», Al-Andalus, 5 (1940), 45-154; al-Amīn, M., Vida y obras de Ibn al-Sìd de Badajoz, T.D. Universidad Complutense de Madrid, 1962; Abū Ŷanāh, S., «Ibn al-Sĩd al-Bațalyawsī, ḥayātu-hu, minhaŷu-hu fĩ 1-nahw wa-1-luga, šicru-hu», Al-Mawrid, 6/1 (1977), 79-116; Ibn al-Sìd, Kitāb al-tanbihh ${ }^{c}$ alà l-asbāb allätī awŷabat al-ijtilāf bayna l-muslimin, El Cairo 1901; (ed. al-Dāya, M.R.) Damasco, $1983^{1}$ y $1987^{2}$, 10-13, y (ed.

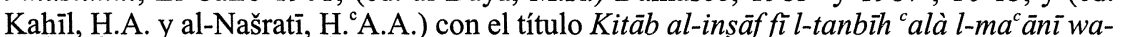
l-asbäb allätī awŷabat al-ijtiläf bayna l-muslimìn, El Cairo $1978^{1}$ y $1982^{2}, 23-33$ (a partir de ahora me referiré a esta obra con la abreviatura Kitäb al-tanbih o Tanbīh); Cruz Hernández, M., Historia de la filosofia hispano-musulmana, Madrid, 1957, I, 295-336; idem, Historia del pensamiento en el mundo islámico. 2. El pensamiento de al-Andalus (siglos $L X-X I V$ ), Madrid, 1996, 416-22 y Peña, S., La obra lingüistica y filológica de Ibn al-Sìd al-Batalyawsī, T.D. ed. en 17 microfichas, Servicio de Publicaciones de la Universidad de Granada, 1988. Una copia de esta edición me ha sido amablemente facilitada por su autor.

5 Esta acepción, junto con la de «león» es registrada en Kazimirski, A. de B., Dictionnaire Arabe-Français, Beirut-París, 1860, s.v.

6 Véase de Epalza, M., «El Cid como antropónimo, ('El león') y como topónimo, ('el señor o gobernador almohade')», Sharq al-Andalus, 7 (1990), 157-69 y 227-36, esp. 232, donde se alude al caso de nuestro Ibn al-Sĩd.

7 Véase, por ejemplo, el de la familia de Yahyà b. Yahyyà en Fierro, M., «El alfaquí beréber Yahyà b. Yahyà al-Layțī (m. 234/848), «El inteligente de al-Andalus» en Ávila, M.L., y Marín, M., (eds.), EOBA, VIII, Madrid, 1997, esp. 272-82. 
lámico; esta vía de integración da paso al ejercicio de funciones administrativas y éstas, a su vez, a la dedicación a la ciencia ${ }^{8}$.

Con Abū Muhammad ${ }^{\mathrm{c} A b d}$ Allāh y su hermano Abū 1-Hasan ${ }^{\mathrm{c}} \mathrm{Alī}$ empieza y termina la corta presencia de la familia en las fuentes árabes. Como veremos, ${ }^{\mathrm{c}} \mathrm{Alī}$ fallece de forma trágica, sin dejar descendientes conocidos. Tampoco los tuvo ${ }^{\mathrm{C}} \mathrm{Abd}$ Allāh, que sepamos, a pesar de su larga vida ${ }^{9}$.

Según Ibn Bassām «Silves era su ciudad de origen y a partir de ella se había puesto en movimiento (wa-Šilb baydatu-hu wa-min-hā kānat harakatu-hu)» ${ }^{10}$. A continuación añade: «Y fue atribuido a Badajoz porque frecuentaba esta ciudad y porque había nacido en su suelo (wa-nusiba ilà Bațalyaws li-taraddudi-hi bi-hã wa-mawlidi-hi fi turbi-hā)». Cuando al proseguir su relato Ibn Bassām afirma: «sea ello como fuere...», parece manifestar una comprensible confusión que para el investigador queda despejada en la noticia que da Ibn Jāqān. Éste precisa que fue el padre de Ibn al-Sīd - y no el propio Ibn al-Sìd - quien se puso en movimiento desde Silves: «Silves era su ciudad de origen y a partir de ella su padre se había puesto en movimiento y había iniciado su andadura ... y fue relacionado con Badajoz por su nacimiento (wa-Šilb baydatu-hu wa-min-hā kānat harakat abi-hi wa-nahdatu-hu... wa-nusiba ilà Bațalyaws li-mawlidi-hi)» ${ }^{11}$. Un autor más tardío, Ibn $\mathrm{Sa}^{c} \mathrm{i} d$ al-Magribī, afirma que Ibn al-Sīd era de Silves ( $k a \bar{a} n a$ min Šilb), pero residía habitualmente en Badajoz, pasando a ser conocido como al-Batalyawsī. Dado que las noticias precedentes son más detalladas y cercanas al biografiado, opto por la versión según la cual Ibn al-Sỉd nació en Badajoz, en el seno de una

\footnotetext{
8 Ténganse en cuenta, en cualquier caso, las observaciones de M. Fierro, en «Árabes, beréberes, muladíes y mawāli. Algunas reflexiones sobre los datos de los diccionarios biográficos andalusíes») en Marín, M. y de Felipe, H. (eds.), EOBA, VII, Madrid, 1995, 41-54. Para el análisis de las cadenas onomásticas de personajes procedentes del actual Algarve portugués, de donde procedía Ibn al-Sīd, véase Marín, M., «A l'extrémité de l'Islam médieval: élites urbaines et islamisation en Algarve», Annales. Histoire, Sciences Sociales, 53/2 (1998), 361-81, esp. 369-73.

${ }^{9}$ Ibn Bassām recoge en su Dajīra un poema que Ibn al-Sīd compuso invocando a uno de sus hermanos, que se llamaba Rāšid. Este mismo personaje es aludido por Ibn Jāqān como Abū l-Hasan Rāšid b. 'Arīf, secretario de al-Ma'mūn, cuya relación familiar con nuestro protagonista parece inexistente. Véase respectivamente Dajir $a$, III, 892 y Azhār al-riyād, III, 113-115 y 132. Así pues quizá debamos pensar que al decir $b a^{c} d$ ijwān, Ibn Bassãm quisiera denotar amistad más que parentesco de sangre.

${ }^{10}$ Esta frase es reproducida por al-Maqqarī en Nafh (ed. Dozy et al.), I, 113.

11 Apud al-Maqqarī, Azhär, III, 105.
} 
familia silvense. Por qué asocia Ibn $\mathrm{Sa}^{\mathrm{c}} \mathrm{i} d$ al-Magribī a Ibn al-Sīd exclusivamente con Silves no deja de ser sorprendente, si tenemos en cuenta la trayectoria vital e intelectual de nuestro protagonista. Es posible que ello deba ser relacionado con una época en que, tras la decadencia de Badajoz, Silves adquiere una cierta relevancia cultural ${ }^{12} \mathrm{y}$ con ella quizá el deseo - que Ibn Sa ${ }^{c} \bar{i} d$ habría querido satisfacer - de reivindicar a los ulemas relacionados por nacimiento o por ascendencia con la ciudad. Las fuentes que he consultado no proporcionan información adicional sobre la relación de Ibn al-Sĩd con Silves.

Los cambios dinásticos suelen brindar la oportunidad de incorporarse a la elite, o de formar una nueva, a aquellos que han recibido una buena educación. El ascenso de los aftasíes, de entre los cuales al-Muzaffar b. al-Afțas fue calificado como «refugio de las gentes cultivadas» ${ }^{13}$, podría haber sido aprovechado por el silvense $\mathrm{Mu}-$ hammad b. al-Sĩd para conseguir algún cargo de tipo administrativo en Badajoz. Resulta verosímil, pues, que fuera el traslado a esta ciudad, más que una hipotética conversión, lo que supuso la fugaz incorporación de la familia a la categoría de los ulemas. Por qué el de Silves probó suerte en Badajoz y no en la equidistante Sevilla es un dato que quizá convendría retener de cara a otro tipo de investigaciones.

\section{Formación en el Badajoz de los aftasíes}

Algunos biógrafos parecen relacionar el mérito de Ibn al-Sīd con sus orígenes silvenses. Sus conocimientos se deben en cualquier caso al aprendizaje con maestros de Badajoz. No he encontrado referencias a maestros silvenses ni en el caso de ${ }^{\mathrm{c}} \mathrm{Ali}$ ni en el de su hermano ${ }^{\mathrm{c}} \mathrm{Abd}$ Allāh Ibn al-Sĩd. La época en la que este último se educa coincide con el reinado de al-Muzaffar Muhammad b. ${ }^{\mathrm{c} A b d}$ Allāh b. Muhammad

\footnotetext{
12 Sobre ello véase Urvoy, D., Le monde des ulémas andalous $d u v^{e} / X I^{e}$ au VII $/ X I I I^{e}$ siècle. Etude sociologique, Ginebra, 1978, 67.

13 Al-Marrākuš̄i, $M u^{c} \hat{y} i b$ (ed. R. Dozy), Leiden, 1881, 53 apud Soravia, B., «Les 'ulamā' andalous au $\mathrm{V}^{\mathrm{e}}$ siècle de l'hégire antagonistes ou courtisans des mulük al-țawä'if'" en Marín, M., y García-Arenal, M. (eds.), Saber religioso y poder politico en el Islam, Madrid, 1994, 293.

14 Para más detalles sobre la dinastía afțasí, véanse Nykl, A.R., «Die Afțasides von Badajoz», Der Islam, 26 (1940), 14-48; Idris, H.R., «Les Afṭasides de Badajoz»,
} 
Ibn al-Afțas (reinó entre 437/1045-460/1068) ${ }^{14}$. En este período al-Andalus experimenta un desarrollo considerable de los estudios coránicos, en especial por lo que se refiere a las lecturas o qirä'ät del texto sagrado. Asimismo, en el siglo V/XI se produce tanto una difusión a gran escala de las colecciones de hadiz como una profundización en su crítica y exégesis, un auge de la ciencia de las fuentes del derecho, una intensificación de la producción escrita sobre temas ascéticos, un florecimiento de las bellas letras y la poesía y un creciente interés por el estudio de la lengua árabe ${ }^{15}$. La astronomía y la agronomía alcanzan su máximo nivel. La matemática experimenta un desarrollo notabilísimo ${ }^{16}$. Con la consolidación del poder político almorávid se afirmó una tendencia que favoreció simultáneamente el estudio de la lengua árabe y del Corán ${ }^{17}$.

El siglo V/XI ha sido calificado como el de mayor esplendor cultural de la historia de al-Andalus. Să $\bar{a}^{-c} i d$ al-Andalusī lo asoció con la dispersión de la biblioteca de al-Hakam II y con la formación de centros culturales en las capitales de los distintos reinos en los que se fragmenta el califato ${ }^{18}$. El mecenazgo oficial, antes centrado en Córdoba, se encuentra ahora repartido por todo el territorio de al-Andalus, requiriendo de los servicios eminentemente propagandísticos de poetas y secretarios, y de instrucción y legitimación por parte de ulemas y alfaquíes. En estas cortes la literatura tiene un papel predominante, otorgándose también una gran importancia a otras ciencias como las

Al-Andalus, 30 (1965), 277-90; Terrón Albarrán, M., El solar de los Aftásidas. Aportación temática al estudio del reino moro de Badajoz. Siglo XI, Badajoz, 1971; Viguera, M.J., «Historia política», HEM, VIII-1, 84-6; idem, «El «reino» de Badajoz en el Mugrib

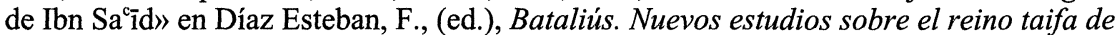
Badajoz, Madrid, 1999, 225-48; Soravia, B., «Al-Muzaffar ibn al-Afțas, signore di Badajoz. Un protagonista dell'epoca delle taifas andaluse», Islam. Storia e Civiltà, 31 (1990), 109-19 y 32 (1990), 179-91 y Rebollo, M.J., La cultura en el reino taifa de Badajoz: Ibn 'Abdün de Évora (m. 530/1135), Badajoz, 1997.

15 Véase Marín, M., «La actividad intelectual», HEM, VIII-1, 505, 513, 518, 519, 526 y 532; para los 'ulüm al-lisān, véase también Peña, S., "Gramáticos en al-Andalus», 43.

16 Véase Vernet, J. y Samsó, J., «La ciencia», HEM, VIII-1, 565-84 y Samsó, J., Las ciencias de los antiguos en al-Andalus, Madrid, 1992, 125-305.

17 Véase Urvoy, D., Pensers d'al-Andalus. La vie intellectuelle à Cordoue et à Séville au temps des empires berbères (fin XI siècle-début XII ${ }^{e}$ siècle), Toulouse, 1990, 131.

18 Țabaqāt al-umam (ed. Bū 'Alwān, H..), Beirut, 1985, 164-5 apud Marín, M., «La actividad intelectual», 504, n. 16 y Llavero, E., «La escuela científica toledana del siglo XI», RIEEI. Las ciudades del Andalus: Toledo, 30 (1998), 266-7. 
empíricas en Toledo ${ }^{19}$ y Zaragoza. Badajoz encaja bastante bien en esta descripción. Ibn al-Jatịb se refiere a los afțasíes como gente de conocimiento y de razón, actitud que habría favorecido el cultivo de las ciencias profanas ${ }^{20}$. Los biógrafos alaban el gusto literario y el interés por la ciencia de al-Muzaffar; ello habría culminado en la composición de una enciclopedia de gran volumen a la que se conoce por el título de al-Muzaffarī ${ }^{21}$. Un fragmento de esta obra ha sido localizado por M. Fierro en la biblioteca $\bar{A} l$ al-Wazir en Yemen ${ }^{22}$. Respecto a su contenido, parece que se trataba de un compendio a partir de obras de gramática, lexicografía, poesía, narraciones curiosas y fuentes históricas, análogo a las Ijtiyārāat de al-Rūhị y a ${ }^{C} U y \bar{u} n$ al-Ajbār de Ibn Qutayba. Dividida en una decena de secciones, cada una de una extensión considerable, al-Marrākušī afirmaba haber leído la mayor parte ${ }^{23}$. Al sucesor de al-Muzaffar, al-Mutawakkil, dedica Ibn al-Jatīb calificativos como «hombre de raciocinio ( $\left.r a^{\prime} y\right)$ y de retórica (baläga)», términos que Gómez Nogales asocia, con la apertura jurídica y filosófica, y con el conocimiento de los comentarios de al-Fārābī a la Retórica de Aristóteles ${ }^{24}$. En favor de esta hipótesis estaría la orientación científica de un personaje como Ibn al-Sīd al-Bațalyawsī que, como veremos, destacó en retórica y compuso una epístola sobre un error cometido por al-Fārābī (v. infra epígrafe 3 y Apéndice 3, n. ${ }^{\circ}$ 9). El hecho de que Abū Ŷ $a^{c}$ far b. Hārūn, uno de los más importantes maestros de Averroes en matemáticas y medicina, fuera originario de Trujillo podría indicar que el interés por las ciencias de los antiguos se mantuvo en la zona tras la conquista almorávid ${ }^{25}$.

19 Véase Marín, M., «La actividad intelectual», 551-5.

20 Kitäb a $a^{c}$ äl al-acläm (ed. Lévi-Provençal, E.), Rabat, 1934, 211, apud Gómez Nogales, S., «La corte de los afțasíes de Badajoz, principalmente en el campo de la filosofia), Actas del IV Coloquio Hispano-Tunecino (Palma de Mallorca, 1979), Madrid, $1983,137-8$

21 Véase Ibn al-Jatịb, ob. cit., 212, apud Gómez Nogales, S., art. cit., 138.

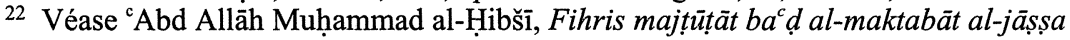
fi l-Yaman (ed. J. Johansen), Londres, 1994, 67 n. ${ }^{\circ} 123$ apud Fierro, M., «Manuscritos en al-Andalus. El proyecto H.A.T.A. (Historia de los Autores y Transmisores Andalusíes)», Al-Qantara, 19/2 (1998), 500 y n. 40.

${ }_{23}$ Histoire des Almohades (trad. Fagnan, E.) Argel, 1893, 63, apud Nykl, A.R., «Aftasides», 29-30. Sobre la preponderancia de las disciplinas literarias en Badajoz en el siglo XI véase también Urvoy, D., Le monde des ulémas, 69.

${ }^{24}$ Ob. cit., 214, apud Gómez Nogales, S., art. cit., 139-40.

25 Véase Gómez Nogales, S., art. cit., 147-8, quien, sin embargo, no tiene en cuenta que el período de formación de Averroes es muy posterior a las taifas. 
La lista de los maestros de Ibn al-Sīd (v. Apéndice 1) es muy corta. Sus biografías, con excepción de la de al-Gassānī, aportan una información bastante escasa. Con los pacenses, entre los cuales el más importante es su hermano ${ }^{\mathrm{c}} \mathrm{Al} \overline{\mathrm{i}}$, aprendió gramática, lexicografía, adab y lecturas coránicas. Con Abū ${ }^{c} \mathrm{Al} \overline{\text { al}}$ al-Gassānī, con quien se formó en hadiz y en fiqh, debió de estudiar también en Badajoz cuando el maestro pasó por allí en 496/1076. No hay rastro de instructores en las ciencias racionales, de manera que resulta difícil apoyar la mencionada hipótesis de Gómez Nogales sobre el desarrollo filosófico en la zona. No hay que olvidar, empero, que la presencia de los sabios dedicados a las ciencias empíricas y racionales en los diccionarios biográficos andalusíes es muy reducida $\mathrm{y}$, de cualquier modo, se registra únicamente cuando el estudio de las ciencias profanas va unido al de las religiosas. Aun cuando se de este último caso, la faceta «no religiosa» de un autor suele aparecer infrarrepresentada ${ }^{26}$. Por otra parte, entre los principales filósofos o proto-filósofos andalusíes, la falta de datos relativa a sus maestros en los ${ }^{c} u l u \bar{m}$ al-awä'il es un hecho recurrente. Sin embargo, tampoco una obra dedicada específicamente a los científicos como es la de Șā̄id, Țabaqãt al-umām, recoge una sola referencia a sabios procedentes de o residentes en Badajoz. De ello podríamos inferir que, o bien la irrelevancia de las ciencias racionales pacenses es una realidad, o bien el autor de las Tabaqāt no pudo registrar un desarrollo que se estaba produciendo en el mismo momento en que él escribía su obra (460/1068) ${ }^{27}$. Dicho florecimiento habría quedado silenciado para siempre ante la falta de obras especializadas posteriores. Lo que sí puede decirse es que si en Badajoz se cultivaron los ${ }^{c}$ ulüm al-awä'il, ello se produjo algo más tarde que en Córdoba, Toledo, Zaragoza, Almería, Denia, Valencia e incluso Calatrava y Cuenca ${ }^{28}$, y que el desarrollo que allí pudieron alcanzar nunca fue lo suficientemente destacado como para traspasar la criba de los autores más tradicionales. En el caso de Ibn al-Sīd caben varias posibilidades. Una es que sus maestros en ciencias de los antiguos no fueran de Badajoz, sino de Toledo o Zaragoza. Otra es que, activos en Badajoz, no fueran musulmanes, sino mozárabes o judíos. Al afirmar que Ibn al-Sīd tuvo además de los que menciona, «otros maestros»,

26 Véase Marín, M., «La actividad intelectual», 505.

27 Para esta fecha, véase Llavero, E., «La escuela científica toledana», 263.

${ }^{28}$ Véase $S \tilde{a}^{c} i d$ al-Andalusī, Țabaqāt, 155-200. 
Ibn Baškuwāl pudo muy bien haber procedido a la manera de Ibn al-Abbār, quien, al reproducir a partir de las Tabaqāt al-umam la noticia relativa a los maestros del lógico Muhammad b. al-Ḥasan b. al-Ḥusayn al-Maḍị̂îi, conocido como Ibn al-Kattānī, omite a los sabios mozárabes bajo el mismo epígrafe de «y otros» ${ }^{29}$. Es posible asimismo que Ibn al-Sīd se iniciara en la filosofía a través del estudio de la lógica, con los gramáticos, y de la retórica, con los $u d a b \bar{a}^{\prime}{ }^{30}$. Tal hipótesis no explicaría, sin embargo, la competencia de Ibn al-Sīd en materia de alquimia (v. Apéndice 3, n. ${ }^{\circ}$ 9), aunque es verdad que pudo haberse interesado por la misma después. Finalmente quizá debamos admitir que no hubo maestros, sino aprendizaje autodidacta.

Ibn al-Sīd no llevó a cabo la rihla a Oriente. Esta es una característica que nuestro personaje comparte con los más importantes lingüistas de su tiempo - Ibn Sĩda y Abū 'Ubayd al-Bakrī-, hecho que, en opinión de M. Marín, es elocuente acerca de la autosuficiencia adquirida por los estudios filológicos andalusíes ${ }^{31}$. Este fenómeno parece no haber afectado únicamente a los especialistas en la lengua árabe, sino que se enmarca en un descenso generalizado de los viajes de ampliación de estudios a Oriente ${ }^{32}$. S. Peña señala que entre los lingüistas, esta tendencia se invierte en el siglo VII/XIII ${ }^{33}$, como resultado, probablemente, del avance de las conquistas cristianas. Que los científicos pudieron encontrar mejor acomodo en los territorios recién conquistados es quizá lo que explica que entre ellos se mantuviera la tendencia regresiva de los desplazamientos a Oriente, hecho que, según J. Samsó y J. Vernet, tuvo consecuencias negativas para su actividad ${ }^{34}$.

Si la falta de alusión a maestros en filosofía y de rị̣la a Oriente son características que Ibn al-Sīd comparte con sus contemporáneos, lo mismo puede decirse de la frecuencia de los desplazamientos, que fue muy común entre los gramáticos andalusíes ${ }^{35}$. Hay que señalar, sin embargo, que inicialmente a Ibn al-Sīd lo encontramos en capita-

\footnotetext{
29 Véase Dunlop, D.M., «Philosophical predecessors and contemporaries of Ibn Bājjah», The Islamic Quarterly, II/2 (1955), 104-8.

${ }^{30}$ Véase supra, valoración de Gómez Nogales.

31 «La actividad intelectual», 535-6.

32 Ibid., 549 y Vernet, J. y Samsó, J., «La ciencia», 581.

33 "Gramáticos en al-Andalus», 47.

34 Véase «La ciencia», 581.

35 Véase Peña, S., «Gramáticos en al-Andalus», 49.
} 
les como Toledo, Albarracín y Zaragoza, las cuales destacan más por el cultivo de las ciencias profanas ${ }^{36}$ que por la preponderancia de los estudios lingüísticos ${ }^{37}$. Con la conquista almorávid y la presencia de Ibn al-Sīd en Córdoba y Valencia, esta tendencia se invierte ${ }^{38}$.

\section{Campos de actuación}

Al decir de sus biógrafos, Ibn al-Sĩd destacó en gramática, lexicografía, bellas letras, poesía y retórica. Se insiste en que era un excelente maestro y un transmisor de hadiz exacto y de fiar. Al-Dahabì hace especial hincapié en esta última faceta. Ibn Jāqān y, siguiéndole, al-Suyūtị hablan de su dedicación a ciencias «nuevas» (hadịta) y «antiguas» (qadima) ${ }^{39}$, sin que «por conocerlas rebasara nunca el recinto de un precepto legal ni se desviara de ningún principio ni regla derivada de la sunna (mā jaraŷa bi-ma ${ }^{c}$ rifati-hä ${ }^{c}$ an midmār šar ${ }^{c}$ wa-lāa nakkaba ${ }^{c}$ an așl li-l-sunna wa-lā far $\left.{ }^{c}\right){ }^{40}$. El hecho de que Ibn Jāqān considere necesario recalcar que la dedicación a las ciencias profanas y la ortodoxia no están reñidas significa que, para muchos, la fe y el pensamiento racional se contradecían. Al-Suyūtī no lo incluye en su Kitāb tabaqāt al-mufassirīn, ya que no debió destacar en la exégesis coránica. Algunos de sus biógrafos (Ibn Baškuwāl, Ibn Jāqān e Ibn Farhūn) le denominan alfaquí. Nunca ejerció, que se sepa, cargo jurídico-religioso alguno ${ }^{41}$.

La mayor parte de las obras conservadas de Ibn al-Sīd han sido editadas (v. Apéndice 3), en algunos casos varias veces. Casi todas

${ }^{36} \mathrm{El}$ interés por la gramática en Zaragoza estaba asociado al estudio de la lógica, según Lomba, J., La filosofia islámica en Zaragoza, Zaragoza, 1991, 177.

${ }^{37}$ Los principales centros eran Granada, Córdoba y Sevilla, según valoración de Peña, S., «Gramáticos en al-Andalus», 49.

${ }^{38}$ Sobre el desarrollo que adquiere el estudio de la lengua árabe en Valencia en el siglo XII, véase Urvoy, D., Pensers, 131 y Marín, M., «La actividad intelectual», 507 y 511. Sobre la vida literaria en Valencia tras la conquista almorávid, véase Guichard, P., Les musulmans de Valénce et la Reconquête ( $\mathrm{XI}^{\mathrm{e}}-\mathrm{XIII}^{\mathrm{e}}$ siècles), Damasco, 1990-91, 81-6.

39 De acuerdo con la definición de los mutakallimūn, la ciencia (cilm) es eterna (qadim) o producida en el tiempo (hadit $\underline{\text { t }}$ ) dependiendo de si existe en Dios o en un ser creado, sin que haya analogía entre ambos tipos. Véase $E I^{2}$ s.v. «ilm» [ED.].

Parece pues que lo que Ibn Jāqān pretende es establecer una distinción entre ciencias religiosas (qadima) y ciencias profanas (hadīta).

40 Apud al-Maqqaīi, Azhār, III, 138.

${ }^{41} \mathrm{Al}$ contrario que otros gramáticos. Véase Peña, S., «Gramáticos en al-Andalus», 48. 
fueron redactadas en forma de comentario, lo cual no es sinónino de falta de originalidad ni de estancamiento ${ }^{42}$, especialmente si tenemos en cuenta que Ibn al-Sīd fue un ulema muy receptivo a las innovaciones, entendidas en su acepción no religiosa.

La contribución de Ibn al-Sīd a las ciencias de la lengua árabe y de sus textos ha sido estudiada por S. Peña (v. nota 4). Éste destaca la ingente erudición de al-Batalyawsī, a quien caracteriza como el principal agente de la introducción de las novedades de los bagdadíes en las «ciencias del lenguaje y el texto» andalusíes. Y no sólo eso. Según S. Peña, Ibn al-Sīd llevó dichas novedades a sus últimas consecuencias, contribuyendo más que ningún otro andalusí, a una revisión crítica de la obra anterior al siglo IV/X. Las autoridades en las que se apoyó, no siempre reconocidas, fueron, entre otros, al-Mubarrad, Ajfaš, Sībawayhi, Jalîl, Ibn Ŷinnī, Abū 'Ubayda, al-Asmā'ī', Ibn al-A'rābī, Abū 'Ubayd, pero sobre todo al-Zaŷŷâŷi, ' ${ }^{\mathrm{A}} \mathrm{Abd}$ al-Qāhir y al-Rummānī. Características singulares de su obra lingüística y filológica son, entre otras, el empleo de šawāhid tardíos, la preferencia dada al Corán sobre los demás componentes del corpus de la lengua árabe, la postura partidaria del convencionalismo en relación con el origen del lenguaje y la postura favorable a los literatos modernos frente a los tradicionalistas; en el debate sobre el nombre y lo nombrado, piensa que ambos no son lo mismo; en poética concibe la labor literaria como producto de un don, pero mucho más como resultado del aprendizaje de una serie de técnicas y temas. La obra poética de Ibn al-Sĩd ha sido analizada también por Ș. Abū Ŷanāh (v. nota 4); de ella H. Pérès traduce algunas muestras escogidas ${ }^{43}$.

El pensamiento filosófico de Ibn al-Sīd, contenido esencialmente en su Kitāb al-hadä'iq, ha sido objeto de numerosos estudios ${ }^{44}$. Re-

42 Véase Peña, S., «La obra lingüística y filológica de Ibn al-Sīd», 1087.

43 Véase Esplendor de al-Andalus. La poesía andaluza en árabe clásico en el siglo XI. Sus aspectos generales, sus principales temas y su valor documental (trad. García-Arenal, M.), Madrid, 1983, 87, 156-7, 242, 320, 372, 376-7, 380, 382.

44 Véanse, entre otros, Kauffman, D., Die Spuren des al-Batlajusis in der jüdischen Religionsphilosophie, Budapest, 1880; Derembourg, H., «Al-Bațalyoūsī», Revue d'Études Juives, 7 (1883), 274-9; Asín Palacios, M., «La tesis de la necesidad de la revelación en el Islam y en la Escolástica», Al-Andalus, 3 (1935), 345-89 e «Ibn al-Sīd de Badajoz y su «Libro de los cercos»»); Domingues, G., «Filosofia e Mística dos Luso-Árabes. I. O Pensamiento Filosófico de Abd Allah Ibn As-sid de Silves», Filosofia, 7 (1960), 127-52; Corbin, H., Histoire de la philosophie islamique, París, 1964, 325-7; Cruz Hernández, M. (véase nota 4); Gómez Nogales, S., art. cit., 143-5; Tornero, E., «Cuestiones filosóficas 
salta el trabajo de edición y traducción de los textos relevantes llevado a cabo por Kauffmann, Asín Palacios, Tornero y Elamrani-Jamal. Ello ha facilitado el camino para posteriores análisis, entre los cuales yo destacaría, aparte de los llevados a cabo por los investigadores que acabo de mencionar, el de Cruz Hernández, por su profundidad, el de Lomba por su claridad y el de Urvoy por su carácter revisionista. Gracias a toda esta labor sabemos que las fuentes de las que bebió Ibn al-Sĩd fueron básicamente las Cartas de los Hermanos de la Pureza (o de los Hermanos Puros, como propuso Stern), de las que procedería su neo-platonismo y su tendencia hacia la conciliación de la fe con el pensamiento filosófico. Las citas a Aristóteles, Platón y al-Fārābī no parecen proceder de una consulta directa de sus obras. Por otra parte, Derembourg pudo comprobar que el primer capítulo de las Hadā'iq puede encontrarse prácticamente calcado en Mīzān al- ${ }^{c} a m a l$ (La Balance des pensées) de al-Gazālī ${ }^{45}$. En general, se pone de manifiesto la novedad, que no la absoluta originalidad, de las ideas filosóficas presentadas por Ibn al-Sīd, sin que se las llegue a considerar constitutivas de un sistema filosófico. Esto parece implicar que Ibn al-Sĩd no debería ser considerado como un verdadero filósofo, a pesar de haberse atrevido a definir qué era la filosofía y quiénes podían ser considerados filósofos (v. también infra, apartado 5, sección relativa a la defensa de al-Waqqašì). La mayoría ha pensado que tal definición podría ser reflejo del estadio en que se encontraban los estudios filosóficos andalusíes en la época de nuestro personaje. Urvoy duda de la representatividad de Ibn al-Sīd en este sentido y de que pueda considerársele un predecesor de los grandes sistemas que se desarrollaron inmediatamente después. Parece que la investigación en la influencia del Kitāb al-hadā'iq sobre los círculos intelectuales judíos (v. infra, apartado 5, sección relativa a Zaragoza) no ha vuelto a despertar interés, tras los trabajos de Kauffman, Derembourg y Asín Palacios, y

del Kitāb al-masä'il de Ibn al-Sīd de Badajoz», Al-Qanțara, 5 (1984), 15-32; Gomes, P., Historia da Filosofia Portuguesa. A Filosofia Arábigo-Portuguesa, Lisboa, 1991, 138-45; Lomba, J., La filosofia islámica en Zaragoza, 175-91; Urvoy, D., Pensers, 172, 176-7 y 196 y «Le raport entre $a d a b$ et falsafa chez Ibn al-Sīd al-Bațalyawsī», próxima aparición en Sidarus, A. y Soravia, B. (eds.), Actas del Simposio «Literatura e Cultura no Gharb al-Andalus», Lisboa, abril-2000; Pacheco, J.A., «Ibn al-Sīd de Badajoz, un neoplatónico errante» en Díaz Esteban, F. (ed.), Bataliús II, 107-20.

${ }^{45}$ Art. cit., 275. 
tampoco lo relativo a otras vías de transmisión a través de discípulos musulmanes ${ }^{46}$.

Ibn al-Sīd puso su profundo conocimiento de la lengua árabe al servicio de la teología ${ }^{47}$, del fiqh y del hadiz (v. Apéndice 3, n. ${ }^{\circ} 10,15$ y 16), ciencias que en ese momento estaban experimentando un considerable desarrollo. Su especialidad le hizo, sin duda, interesarse más por el texto de las tradiciones que por sus cadenas de transmisión. En el Tanbih se refleja su excelente conocimiento de los tratados de discrepancia del hadiz y su preferencia por los tradicionistas frente a los alfaquíes. Aunque Ibn Farḥūn lo considera mālikí, Ibn al-Sīd no parece comprometido con esta doctrina. Profesa, más bien, una postura en la que se consideran válidas las máximas de mālikíes, šãfííes y hanafíes. Esta actitud podría deberse a la influencia de Ibn 'Abd al-Barr, de quien había sido discípulo su maestro $A b \bar{u}{ }^{c} A l i ̄$ al-Gassānī. Las doctrinas de hanbalíes y zāhiríes parecen ir englobadas bajo el apelativo de «literalistas», utilizado con una connotación negativa. En cuanto a sus tendencias teológicas, su defensa del punto medio entre qadaríes y ŷabríes, su actitud favorable a la interpretación alegórica de los antropomorfismos de la Revelación y su aceptación de la afirmación de los atributos divinos apuntan a una orientación ašcarí, a pesar de que en el debate sobre el nombre y lo nombrado sostenía la opinión contraria a su equiparación, la cual solía atribuirse a los $\mathrm{mu}^{\mathrm{c}}$ tazilíes ${ }^{48}$. En mi trabajo «Ibn al-Sīd al-Bațalyawsī y su obra sobre la discrepancia entre los musulmanes» presento una primera aproximación al contenido del Kitāb al-tanbīh ${ }^{49}$.

En Ibn al-Sīd se da una conjunción entre teología-lengua-lógica por una parte, lengua- $a d a b$ por otra y finalmente lengua-lecturas coránicas-tradición, que es igualmente observable en otros personajes del período de las taifas ${ }^{50}$. En el siglo XII, se mantiene la relación len-

46 Creo que es digno de reseñar que la única copia manuscrita que existe de la obra es de escritura oriental. Véase Asín Palacios, M., «Ibn al-Sīd de Badajoz y su «Libro de los cercos», 55, n. 2.

47 Mientras que las implicaciones teológicas de algunas cuestiones lingüísticas supusieron un motor en el avance de las denominadas ciencias de la palabra. Véase Peña, S., La obra lingüistica y filológica de Ibn al-Sìd, 1095.

48 Véase Peña, S., La obra lingüistica y filológica de Ibn al-Sid, 1107.

49 Aparecerá también en Actas del Simposio Literatura e Cultura no Gharb al-Andalus, Lisboa, abril-2000.

50 Véase Marín, M., «La actividad intelectual», 528-9 y 535-6; Urvoy, D., Pensers, 131 y Peña, S., «Gramáticos en al-Andalus», 50. 
gua- $a d a b$ y gramática-lecturas coránicas, apreciándose una especie de ruptura entre filología y derecho ${ }^{51}$ que podría explicar las razones por las cuales en su Kitäb al-tanbïh, Ibn al-Sīd insiste en la necesidad de mejorar la formación lingüística de los estudiantes de fiqh.

Algunas de sus obras (v. Apéndice 3 n. $^{\circ} 4,9$ y 17 ) reflejan las polémicas que sostuvo con Abū Bakr Ibn al- ${ }^{\mathrm{c} A r a b i ̄ ~ e ~ I b n ~ B a ̄ y ̂ y ̂ a . ~ S u ~ e s-~}$ tudio detenido podría aportar claves para comprender qué era lo que estaba en juego en esta pugna, más allá de la mera competencia intelectual.

\section{Enseñanzas e influencia}

Según el cómputo de D. Urvoy a partir de la Takmila de Ibn al-Abbār, Ibn al-Sīd es mencionado 17 veces hasta 565/1170, 14 veces hasta 585/1189 y una vez después, ocupando el tercer puesto en importancia entre los maestros de quienes murieron entre 540/1145 y $585 / 1189^{52}$. No siempre es posible saber si el discípulo en cuestión asistió a las clases del maestro o si únicamente solicitó y obtuvo su iŷāza. En cualquier caso, de la relación de sus discípulos (v. Apéndice 2) se desprende que la actividad docente de Ibn al-Sīd tuvo lugar en Córdoba y sobre todo en Valencia, donde aparece ya como un maestro plenamente reconocido. Quienes asistieron a sus clases fueron en su mayoría alfaquíes y tradicionistas, muchos de los cuales ocuparon después cargos de tipo jurídico-religioso. A través de sus biografías se aprecia la gran influencia de otros maestros como Abū ${ }^{\mathrm{c}}$ Alī al-Sadafī, Abū Bakr Ibn al- ${ }^{\mathrm{c}}$ Arabī e Ibn al-'Arīf. Uno de esos discípulos fue cadí de Ibn Qasī (n. $\left.{ }^{\circ} 4\right)$. De otro (n. ${ }^{\circ}$ 9) se dice que tendía hacia la interpretación literal en hadiz y en fiqh. La rihla a Oriente realizada por algunos fue fundamental para la transmisión de la obra de Ibn al-Sīd fuera de al-Andalus. Aquellos entre los que más influencia ejerció parecen ser el n. ${ }^{\circ} 1$ y 20.

\footnotetext{
51 Véase Zanón, J., «La actividad intelectual» en Viguera, M.J. (coord.) et al., El retroceso territorial de al-Andalus. Almorávides y almohades. Siglos XI al XIII, HEM, VIII-2, Madrid, 1997, 569.

52 Véase Le monde des ulémas andalous, 167-8.
} 


\section{Ibn al-Sĩd al-Bațalyawsī: un ulema en busca de acomodo}

Las razones por las que Ibn al-Sīd abandonó Badajoz podrían estar relacionadas con la inestabilidad política en dicho reino. Tras la muerte de al-Muzaffar en 461/1068-9, sus dos hijos Yahyà al-Manșūr

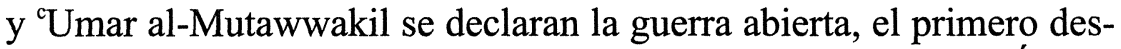
de la capital y el segundo, prácticamente independiente, desde Évora. Yahyà recibió el apoyo del monarca toledano al-Ma'mūn, y 'Umar el del ' ${ }^{\circ} a b b a ̄ d i ́ ~ a l-M u^{c}$ tamid. La guerra terminó con la muerte de Yahyà, instalándose ${ }^{C}$ Umar en Badajoz tras dejar a su hijo al- ${ }^{\mathrm{C}} \mathrm{Abbās}$ al mando de Évora ${ }^{53}$. La hipótesis de que los hermanos Banū 1-Sīd hubieran pertenecido al bando favorable a Yahyà podría explicar la muerte de ${ }^{c}$ Alī Ibn al-Sĩd en Calatrava a manos de Ibn ' ${ }^{c}$ kkāšā — gobernador de la plaza, fiel quizá a 'Umar al-Mutawwakil - y la salida de su hermano ${ }^{\mathrm{C}} \mathrm{Abd}$ Allāh hacia Toledo, en un ambiente de constantes hostilidades entre al-Mutawakkil y al-Qādir ${ }^{54}$. La salida de Badajoz tendría que haberse producido con posterioridad a 496/1076, año en que al-Gassānī pasa por la ciudad, pudiendo nuestro gramático asistir a sus clases. Esta fecha podría servir asimismo para delimitar la de la muerte de Yahyà al-Manșūr, que no se sabe con certeza ${ }^{55}$.

\section{En Toledo}

Según la biografía de Ibn Jāqān, Ibn al-Sīd habría estado en la corte del fundador de la dinastía Dū 1-Nūn, al-Zãfir ${ }^{\mathrm{c}} \mathrm{Abd}$ al-Rahmmān b. 'Ubayd Allāh ${ }^{56}$, señor de Santaver, Huete, Uclés y Cuenca ${ }^{57}$, cuyo traje de gala describe el de Badajoz ${ }^{58}$. Ello es, sin embargo, cronológicamente imposible. Ibn Jāqān afirma que Ibn al-Sīd le contó que asistió junto con al-Ma'mūn (reinó entre 435/1043-4-467/1075) a su sesión literaria (mâylis) de al- $\mathrm{Na}^{\mathrm{c}}$ ūra ${ }^{59}$, componiendo un poema para la ocasión. Resulta difícil aceptar que al-Bațalyawsī se encontrara en

53 Véase Idris, H.R., «Les afțasides», 284-7.

54 Véase infra.

55 Véase Idris, H.R., art. cit., 286, n. 34

56 Apud al-Maqqaīi, Azhār, III, 117-20 y 127-9.

57 Sobre este personaje, véase Viguera, M.J., Los reinos de taifas y las invasiones magrebies, Madrid, 1992, 54.

58 Véase Pérés, H., Esplendor de al-Andalus, 242.

59 Qalä'id, 222. 
Toledo antes de 467/1075, pues hemos visto que estudió con al-Gassānī y que ello debió de suceder en 496/1076, a menos que hubiera visitado al maestro en Córdoba. Ibn Bassām, que recoge el mismo poema, parece notar el problema y se limita a hablar de Ibn Dī 1-Nūn ${ }^{60}$. En vista de estas contradicciones habría que pensar que en realidad se trataba de agradar al mecenas efectivo, al-Qādir, mediante la alabanza de sus antepasados. Es posible también que los hermanos Banū 1-Sīd vivieran entre Badajoz y Toledo por desempeñar algún cargo de tipo diplomático para el monarca pacense. En favor de la presencia de Ibn al-Sīd ante al-Ma'mūn se cuenta una invitación a beber vino $\left(m u^{c} \bar{a} t \bar{a} t \text { t qahwa }\right)^{61}$ de parte del secretario de al-Ma'mūn, Abū l-Hasan Rāšid b. ${ }^{~} A$ Arif ${ }^{62}$. Anteriormente Ibn al-Sīd se había dirigido a él por escrito, consiguiendo que el kātib le invitara a formar parte de su maŷlis uns ${ }^{63}$, descrito luego por el pacense ${ }^{64}$.

La aparición de Ibn al-Sīd como poeta aúlico en la corte de al-Qādir Ibn Dīi l-Nūn ${ }^{65}$ (reinó entre 467/1075-478/1085) no plantea, en principio, ningún problema ${ }^{66}$. A la etapa toledana corresponden también unos versos en respuesta a un poema del maestro Abū Muhammad [Mūsà b. ${ }^{\mathrm{c}} \mathrm{Abd}$ al-Raḥmān] Ibn Ŷawšan ${ }^{67}$. Dada la fecha de muerte del personaje, Ibn al-Sīd difícilmente pudo conocerle. Debe tratarse pues de un complemento, de una réplica póstuma o de otro personaje que no me es imposible localizar.

En Toledo el ambiente era favorable a las «ciencias de los antiguos», promocionadas por la propia dinastía reinante. De la pujanza de estos estudios en el siglo XI es buena prueba que de esta taifa saliera el famoso y ya mencionado Kitāb tabaqāt al-umam, historia de las

${ }^{60}$ Dajīra, 894.

61 Vino es una de las acepciones habituales de qahwa porque, según al-Raqīq al-Qayrawānī, «quien lo bebe a menudo pierde el apetito»; véase idem, al-Mujtār min quṭb al-surür fi wașf al-anbiḍa wa-l-jumür (ed. Manșūr, 'A. al-Ḥ.) Túnez, 1976, 31.

${ }^{62}$ Apud al-Maqqaīi, $A z h \bar{a} r$, III, 132, donde en vez de ${ }^{\mathrm{c}}$ Arif encontramos 'Urayb. Adī $\bar{b}$ y poeta, versado en retórica, de los personajes principales de Guadalajara. Véase Ibn Sa'īd, Mugrib, II, 350 y supra, apartado 1.

${ }^{63}$ Apud al-Maqqarī, Azhãr, III, 113-5.

${ }^{64}$ Ibid, 115-6.

${ }^{65}$ Ibid, 107-8, 135-7.

66 Aunque E. Terés no cita a Ibn al-Sīd entre los poetas de la corte de al-Qādir. Véase «Le Développement de la civilisation arabe à Tolede», Cahiers de Tunisie, 18 (1979), 78-86.

${ }^{67}$ Ibid, 139-40. De la gente de Toledo, destacaba por sus buenas maneras y su carácter afable, m. 448/1056. Véase Ibn Baškuwāl, Șila n. $^{\circ} 1343$. 
ciencias compuesta por el toledano Abū 1-Qāsim Sẵ $\bar{a}^{-c}$ d b. Ahmad b. 'A Abd al-Rahmān b. Muhammad b. Sa $a^{c} 1 \bar{d}$ al-Andalusī, así como la intensa labor de traducción de obras científicas ${ }^{68}$.

\section{En Albarracín}

Verosímilmente, Ibn al-Sīd abandona Toledo ante la creciente inestabilidad política agudizada en 473/1080-474/1081 ${ }^{69}$. Teniendo en cuenta los acontecimientos históricos a los que antes he hecho referencia, Ibn al-Sīd pudo haber salido - huyendo y no por gustoante la entrada de al-Mutawwakil Ibn al-Afțas en la capital de los Dū 1-Nūn. En Albarracín gobernaba ${ }^{\mathrm{C}} \mathrm{Abd}$ al-Malik b. Razīn (entre 450/1058-496/1102) a quien alaba el de Badajoz ${ }^{70}$, consiguiendo del rey «la más elevada situación». Más tarde la relación entre ambos se enturbió.

\section{En Zaragoza}

En Zaragoza lo encontramos en tiempos de al-Musta ${ }^{\mathrm{i}}$ in bi-Llāh Ahmad b. Sulaymān b. Hūd ${ }^{71}(478 / 1085-501 / 1107)$, para quien Ibn al-Sīd compuso un panegírico ${ }^{72}$. Allí se refugió tras haber sido encar-

68 Véase Terés, E., «Le Développement de la civilisation arabe à Tolede», Cahiers de Tunisie, 18 (1979), 78-86; Ramón Guerrero, R., «La filosofia en la corte de al-Ma'mūn de Toledo», Simposio Toledo Hispanoárabe, Toledo, 1986, 15-25; Fierro, M., «El proceso contra Ibn Haātim al-Tulayțulī (años 457/1064-464/1072) en Marín, M., (ed.), EOBA, VI, Madrid, 1994, 199-200 y 211-2, n. 73 y 74; Toral, I., «Yahyā b. al-Hadīdī, un notable en la corte de los Dū 1-Nūn de Toledo», EOBA, VI, 400; Arvide, L.M., «La escuela de traductores de Toledo y la ciencia árabe», Las ciudades del Andalus: Toledo, RIEEI, 30 (1998), 109-26 y Llavero, E., «La escuela científica toledana del siglo XI».

${ }_{69}$ Cuando Toledo pasa a manos de al-Mutawwakil de Badajoz. Sobre este interregno, véase Pacheco, J.A., "UUmar al-Mutawakkil ibn al-Afțas de Badajoz, rey de Toledo: crónica de un poder efímero», Simposio Toledo hispanoárabe, 61-73. En 474/1081 al-Qādir es repuesto por Alfonso VI hasta 478/1085, año en que la ciudad pasa definitivamente a manos cristianas.

70 Apud al-Maqqarī, Azhār, III, 123-5. Sobre esta etapa y la siguiente, véase Lomba, J., «El filósofo Ibn al-Sĩd y su paso por Albarracín y Zaragoza», Studium, Teruel, 1987, 73-85.

71 Apud al-Maqqarī, Azhär, III, 121.

72 En el cual, por cierto, Ibn al-Síd sitúa su estancia en Albarracín después de su marcha a Zaragoza. En mi opinión se trata de un recurso poético para acentuar el mérito de la segunda sobre la primera. 
celado por Ibn Razīn, consiguiendo escapar ${ }^{73}$. Aquí Ibn al-Sīd ${ }^{74}$ aparece manteniendo un debate con el filósofo Ibn Bāŷŷa, a quien acusa de querer introducir el arte de la lógica en el de la gramática ${ }^{75}$. Parece que el debate no resultó favorable a Ibn al-Sīd y que traspasó los círculos intelectuales, pues el pacense no sólo se defendió ante sus colegas (v. Apéndice 3, n. ${ }^{\circ} 9$ ), sino que tuvo que hacerlo también ante tres visires (v. Apéndice 3, n. $^{\circ} 17$ ), entre ellos Abū Muhammad ${ }^{\mathrm{c}} \mathrm{Abd}$ Allāh b. Sufyān b. Sīd Allāh al-Tuŷībī ${ }^{76}$.

Dada la importancia que el cultivo de los estudios filosóficos adquirió en Zaragoza ${ }^{77}$, es muy posible que en ella Ibn al-Sid pudiera ampliar sus conocimientos en la materia. A través de esta capital habían ganado audiencia las epístolas de los Ijwān al-safā', traídas a al-Andalus tras su viaje a Oriente por el cordobés afincado en Zaragoza Abū 1-Hakam ${ }^{\mathrm{c} A m r}$ b. ${ }^{\mathrm{c}} \mathrm{Abd}$ al-Rahmān b. Ahmmad b. ${ }^{\mathrm{c}} \mathrm{Alī}$ al-Kirmānī ${ }^{78}$. A la penetración de esta obra se atribuye el florecimiento de la filosofía en al-Andalus. En Zaragoza vivía asimismo una comunidad judía que desempeñaba una intensa actividad intelectual ${ }^{79}$. Al contacto con ella durante esa época podría deberse la traducción hebrea del Kitäb al-hadā'iq por parte del rabino de Marsella Moses ibn Tibbon (1240-1283), publicada por un judío de Guadalaja-

Un extracto de este poema es transmitido por Yāqūt, $M u^{c} \hat{y} a m$ al-buldān, El Cairo, 1906, 10 vols., V, 301 y al-Qazwīnī, Ātār al-bilād, Beirut, 1960, 543. Agradezco a A. Sidarus esta información. Ambos geógrafos relacionan, creo que erróneamente, el topónimo Santamaría con Santamaría de Algarve.

73 Apud al-Maqqarī, Azhār III, 121 e Ibn Bassām, Dajīra, II, 895.

74 Que según la impresión de E. Tornero parece ser gozaba de una extendida fama de filósofo, véase «Cuestiones filosóficas», 15-6. 77-8.

75 Véase Elamrani-Jamal, A.J., «Les rapports de la logique et de la grammaire»,

${ }_{76}$ Apud al-Maqqarī, Azhār, III, 142-5. Literato, poeta y secretario originario de Cuenca, que también se interesó por la lexicografia, por la historia y por el hadiz. Fue visir de los Banū Dī l-Nūn en Santaver y murió en 513/1119. Véase Ibn al-Abbār, Takmila (ed. Harrās, ${ }^{\mathrm{c} A}$ A.S.), II, n. ${ }^{\circ} 718$.

77 El interés del rey al-Muqtadir b. Hūd (reinó entre 438/1046-474/1081) por la astrología, la filosofía y la geometría es destacado por al-Šaqundī en su famosa Risāla. Véase Dunlop, D.M., art. cit., 108. Para más detalles, véase Lomba, J., La filosofia islámica en Zaragoza. 529.

78 Véase Șẫid al-Andalusī, Tabaqāt, 171-2 y Marín, M., «La actividad intelectual»,

${ }^{79}$ En el siglo XII, Zaragoza, más que Toledo, se convierte en el centro de traducción desde el cual la cultura árabe pasa a Occidente. Véase Urvoy, D., Pensers, 165. 
ra, Samuel ibn Moțot, con el título $H a-^{c}$ agullot ha-rac yoniyyot y editada por D. Kauffman ${ }^{80}$.

Zaragoza fue tomada provisionalmente por los cristianos en 512/1118. Mucho antes de esa fecha Ibn al-Sīd debió de abandonarla con destino a Córdoba, donde ocupó el cargo de alto secretario y, por lo que se desprende de la biografía de uno de sus discípulos (v. Apéndice $\left.2, \mathrm{n}^{\circ} 15\right)$, se dedicó a la enseñanza de la poesía.

\section{El paso a la administración almorávid: Córdoba}

Según al-Qifți (nacido en Egipto 568/1172), al-Ṣafadī (m. Damasco 764/1363) y al-Suyūṭi (nacido en El Cairo 849/1445), Ibn al-Sīd vivió en Córdoba en tiempos de Muhammad b. al-Hāâŷy. Este personaje fue wäli almorávid de la ciudad entre 483/1090 y 499/1106, año este último en que es relevado del gobierno de Córdoba para serle encomendado el de Valencia ${ }^{81}$. Puesto que los tres biógrafos mencionados coinciden en situar la etapa valenciana inmediatamente después de la cordobesa y que Ibn Jāqān sitúa la marcha a Zaragoza directamente tras la estancia en Albarracín, puede confirmarse la secuencia Albarracín-Zaragoza-Córdoba-Valencia.

Con Ibn al-Hāŷŷy ejerció Ibn al-Sīd como alto secretario (wa-kāna $k a \overline{t i b u}$-hu ${ }^{c}$ aliyyu l-kātib) «estando los asuntos de la ciudad depositados en sus manos». El almorávid tenía tres hijos, ${ }^{\mathrm{c}}$ Azzūn, Rahmūn y Hassanūn, que eran muy guapos, y que despertaron los deseos, así lo dice al-Qiftīi, del pacense. Entonces compuso unos versos en los que lo manifestaba claramente. Según al-Qifțī y al-Suyūtị, tras dar rienda suelta a sus impulsos, Ibn al-Sīd temió que el padre de los muchachos se enterara y huyó de Córdoba a Valencia. Aunque la noticia de la

${ }^{80}$ Die Spuren des al-Batlajusis in der jüdischen Religionsphilosophie, Budapest, 1880. Véase Asín, M., «Ibn al-Sīd de Badajoz y su «Libro de los cercos»"», 53-4. Véase también Vajda, G., «Une version hébraïque inconnue des 'Cercles imaginaires de Batalyawsi'» en Semitic Studies in Memory of Immanuel Löw, Budapest, 1947, 202-4. El Mizān al- ${ }^{c}$ amal de al-Gazālī — que como hemos visto pudo ser una de las fuentes utilizadas por Ibn al-Sīd en sus Hadä'iq - fue traducido al hebreo por un judío de Barcelona llamado Abraham b. Hasday b. Samuel Halafay, al igual que otras obras de contenido filosófico del mismo autor. Véase Šaḥlān, A., «Al-Gazālī fī manzūmat al-fikr al-yahūdī. Fuqahā' al-yahūd wa-l-fikr al-falsafì» en Abū Hāmid al-Gazālī. Dirāsāt fi fikri-hi wa- ${ }^{c} a s ̦-$ ri-hi wa-ta'tíri-hi, Rabat, 1988, 195-213, esp. 198.

81 Véase Bosch Vilá, J., Los almorávides, Granada, 1990, 150-1 y 177. 
huida parece cierta, como se verá, resulta problemática por varias razones que expondré más adelante. Antes conviene detenerse en el contenido de los versos y en las razones que pudieron justificar el temor del poeta.

A simple vista podría pensarse que pudo ser la homosexualidad -y la pederastia- de Ibn al-Sīd el origen de las iras de Ibn al-Hâŷyŷ. Ahora bien, la mera composición de unos versos en los que un poeta proclama su amor por un muchacho no significa necesariamente que el poeta sea homosexual. La poesía dedicada a los efebos es un género muy característico de la literatura árabe medieval que puede cultivarse con la sola intención de ejercitarse en ese arte ${ }^{82}$, sin que los sentimientos a los que se alude hayan de ser sinceros o reales. En caso de serlo, en el Islam medieval lo que se rechazaba no era el amor hacia una persona del mismo sexo, sino la consumación del mismo en una relación sexual, no considerándose lícita más que la que tiene lugar entre hombre y mujer en el seno del matrimonio o del concubinato, y en este último caso sólo entre el hombre y su esclava. Sin embargo, la visión según la cual el acto homosexual no se concebía como una desviación, sino como una relación sexual ilícita igual que la que se produce entre hombre y mujer fuera del matrimonio o del concubinato no parece haber gozado, en mi opinión, de aceptación unánime ${ }^{83}$, al menos entre los juristas ${ }^{84}$.

Desde esta óptica, los versos de Ibn al-Sīd, cuya traducción sigue, pueden considerarse de lo más casto, especialmente si se comparan con lo que poetas como Abū Nuwās o Ibn Quzmān produjeron en el mismo género:

${ }^{82}$ Agradezco esta observación a T. Garulo.

${ }^{83}$ Cfr. Monroe, J.T., "The Striptease That Was Blamed on Abū Bakr's Naughty Son: Was Father being shamed, or was the Poet having Fun (Ibn Quzmān's Zajal No. 133)» en Wright, J.W. y Rowson, E.K., (eds.), Homoeroticism in Classical Arabic Literature, Nueva York, 1997, 116-7.

${ }^{84}$ Sobre el tratamiento de la homosexualidad en la jurisprudencia islámica a partir del Corán, del hadiz y de la Muhallà de Ibn Hazm, véase Adang, C., «Ibn Hazm on Homosexuality. A Case-Study of Zāhirī Legal Methodology», próxima publicación en Al-Qantara. Gracias a este artículo, cuya autora me ha permitido consultar antes de su publicación, he podido examinar cuáles eran, según Ibn Hazm, las diferentes posturas de los juristas respecto al acto homosexual. Véase también Crompton, L., «Male love and Islamic law in Arab Spain» en Murray, S.O. y Roscoe, W., (eds.), Islamic homosexualities: culture, history and literature, Nueva York, 1997. 
Oculté mi mal hasta que casi me ocultó a mí/ amé perdidamente a causa de ${ }^{c}$ Azzūn y me dieron el pésame

Después me dijeron: «Dios se apiade de ti» por Raḥmūn/ y cuando mi alma deseó la saliva de Hassanūn, sintieron lástima de mí.

Si ni la homosexualidad ni la reducida carga erótica del poema parecen susceptibles de haber provocado escándalo alguno, sí podría haberlo sido la declaración pública de ese amor. Aunque el poeta se presenta persiguiendo un objetivo inalcanzable dada la posición social de los amados ${ }^{85}$, hay que tener en cuenta que en el Islam clásico este tipo de manifestaciones, en las que se involucraba a mujeres adultas, a jovencitas o a jovencitos, se consideraban una manera certera de ofender a sus parientes varones ${ }^{86}$, y eso debía saberlo muy bien Ibn al-Sĩd. Entonces, o nos encontramos ante una imprudencia por su parte, producto de un impulso irreprimible, o se trata de una dádiva envenenada cuyo verdadero alcance el poeta habría creído no poder ser apreciado por el almorávid. Pero éste debía tener sus consejeros; incluso es posible que alguno de ellos aprovechara la ocasión para librarse de Ibn al-Sīd.

Independientemente de si Ibn al-Ḥâŷy se tomó los versos de su secretario como una sátira o como un panegírico, lo cierto es que ello fue interpretado en tono de sátira por quienes los transmitieron, y al hacerlo, podrían haberse dejado llevar por sus prejuicios. De hecho, el relato con que es introducido el poema, y según el cual Ibn al-Sĩd habría observado a los muchachos de lejos, en las galerías del patio de la mezquita de Córdoba, sin poder acercarse a ellos por tratarse de los hijos del gobernador, parece responder a otro tópico frecuente en la poesía amorosa ${ }^{87}$.

La noticia según la cual Ibn al-Sīd huyó de Córdoba a Valencia resulta problemática además por otras razones: en primer lugar, sólo la transmiten al-Qifțī y al-Suyūtīi. Al-Maqqarī la reproduce, pero duda de su veracidad ${ }^{8}$. Al-Safadí se limita a transcribir los mencionados versos sin hacer más comentarios. Por otra parte, ya se ha dicho que

\footnotetext{
${ }^{85}$ Este es un tema que se repite en otros poemas como en el zéjel n. ${ }^{\circ} 133$ de Ibn Quzmān. Véase Monroe, J.T., art. cit., 100.

86 Ibid., 101 y ss.

${ }^{87}$ Véase un poema similar de $A b \bar{b}{ }^{c}$ Āmir b. Šuhayd, citado por Monroe, J.T., art. cit., 107-8.

88 Véase Nafh (ed. Dozy, R., et al.), II, 195 y 310 y Azhār, III, 103.
} 
Ibn al-Hāŷŷy fue nombrado gobernador de Valencia en 499/1106 y no tenemos constancia de que Ibn al-Sīd, que ya se encontraba en la ciudad en esa fecha, decidiera abandonarla ante la llegada del almorávid.

Sin embargo, en virtud de la crítica literaria y de los tanteos de Ibn al-Sīd ante personajes influyentes del área levantina con anterioridad a la definitiva conquista almorávid, la veracidad de la huida es posible. Es significativo, por otra parte, que Ibn Jāqān, que contó con datos proporcionados por el propio autor y que escribió en vida de éste ${ }^{89}$, no haga una sola mención a la relación de Ibn al-Sīd con Córdoba y con Ibn al-Hāŷy. Parece evidente que se trataba de un capítulo delicado en la vida del biografiado.

Levante: de vuelta al mecenazgo de las taifas, sumisión a un gobernante cristiano y definitiva integración en la vida intelectual del periodo almorávid

Su establecimiento en Valencia parece previo, como ya he señalado, a una serie de tentativas ante personajes influyentes de la zona. Primero se habría dirigido a Dū l-wizāratayn Abū 'îsà Lubbūn b. ${ }^{\mathrm{c}} \mathrm{Abd}$ al- ${ }^{\mathrm{c}} \mathrm{Azīz}$ b. Lubbūn ${ }^{90}$, quien le convocó a su maŷlis. Un hermano del visir había muerto e Ibn al-Sīd compone un poema de condolencia. Activo en Murviedro y en Santamaría de Levante, Ibn Lubbūn se mantuvo más o menos independiente en Murviedro = Sagunto hasta 486/1092-93, año en que cede su dominio al emir de Albarracín, ${ }^{\text {c} A b d ~ a l-M a l i k ~ b . ~ H u d a y l ~ b . ~ R a z i n n ~}{ }^{91}$. La marcha de Ibn al-Sìd hacia Levante tuvo que producirse, pues, antes de 486/1092-3.

Ante las nuevas circunstancias políticas, Ibn al-Sīd se pone en contacto con personajes activos en Valencia. Se conserva un panegírico en honor de Dü l-wizāratayn Abū Muhammad Ibn al-Faraŷy ${ }^{92}$, gobernador de Cuenca fiel a al-Qādir, al cual acogió cuando perdió su reino. Este Ibn al-Faraŷ parece ser el mismo que gobernó después Valencia en nombre del Cid ${ }^{93}$. Al-Bațalyawsī solicitó también la ayuda del visir Abu ${ }^{\mathrm{c}} \mathrm{Abd}$ al-Malik b. ${ }^{\mathrm{C}} \mathrm{Abd}$ al- ${ }^{\mathrm{c}} \mathrm{Aziz}$, para quien compuso una

\footnotetext{
${ }^{89}$ Véase $E I^{2}$, s.v. «al-Fatḥ b. Khāqān» (Ben Cheneb, M.-[Pellat, Ch.].

90 Apud al-Maqqarī, Azhär, III, 120 y 146-7.

91 Véase Ibn al-Abbār, al-Hulla al-siyarā' (ed. Mu'nis, Ḥ.), El Cairo, 1963, II, 135.

92 Apud al-Maqqarī, Azhär, III, 145-6.

93 Véase Viguera, M.J., Los reinos de taifas, 58 y 81 .
} 
elegía ${ }^{94}$. De tratarse del mismo personaje que luego se haría con el poder en Valencia en 540/1145 frente a los almorávides ${ }^{95}$, es imposible que Ibn al-Sīd le sobreviviera. Por tanto, la elegía o está dedicada a otro miembro de la misma familia, o es en realidad un panegírico.

Las relaciones tanto con Ibn Lubbūn como con Ibn al-Faraŷ podrían haberse iniciado ya en la etapa toledana.

Así pues, tras una breve estancia en Sagunto, Ibn al-Sīd se habría marchado a Valencia, que en ese momento había caído o estaba a punto de caer en manos del Cid (gobernó en Valencia desde 487/1094 hasta su muerte en 492/1099, aunque el dominio cristiano se prolongó hasta 496/1102).

El poema en el que respondía a otro de $A b u \bar{~}{ }^{c} A b d$ Allāh b. Abī 1-Jișāl ${ }^{96}$, secretario de ${ }^{c} A l i ̄$ b. Yūsuf (gobernó entre 499/1106$538 / 1143$ ), podría haber supuesto el perdón por el episodio de Córdoba y el establecimiento de buenas relaciones con la cúpula almorávid de Valencia. Ello podría haber sucedido después de la llamada «defensa de al-Waqqašì (v. infra y Apéndice 3, n. $^{\circ}$ 9), que tiene lugar en esa ciudad después de 489/1095, fecha de la muerte del ulema toledano, y que apuntaría a una época en que la ortodoxia de Ibn al-Sīd fue puesta en duda ${ }^{97}$. Ibn Jāqān cuenta que Ibn al- ${ }^{\mathrm{c}} \bar{A} s \overline{1}^{98}$ presiónó a Ibn al-Sĩd «cuando reclamó daño y no beneficio» ${ }^{99}$. La imprecisión del biógrafo no es sólo resultado de su estilo literario, sino del deseo de no comprometer a Ibn al-Sīd, que quizá aún vivía cuando se narraban estos hechos. Si tenemos en cuenta que Ibn al- ${ }^{\mathrm{c}} \mathrm{A}$ și ejerció en Valencia la jutțtat al-mawāriț y que su cargo aparece ligado a la hisba ${ }^{100}$, podemos imaginar que Ibn Jāqān se refiere veladamente a una especie de mihnna, de la cual Ibn al-Sīd salió incluso beneficiado, a juzgar por

94 Apud al-Maqqarī, Azhār, III, 125-7.

95 Véase Viguera, M.J., Los reinos de taifas, 196-7. Sobre la familia de los Banū ${ }^{\circ}$ Abd al-'Azīz, véase Ibn Jāqān apud Azhār, III, 125 y Guichard, P., Les Musulmans de Valence, 102,110 y 318.

96 Apud al-Maqqarī, Azhār, III, 133-4.

97 Algo que ya apunta S. Gómez Nogales en «La corte de los afțasíes», 144.

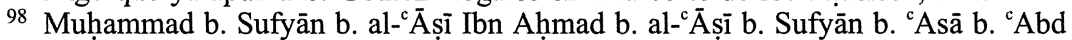
al-Kabīr b. Sa ${ }^{\mathrm{c}} \overline{1} \mathrm{~d}$ al-Asadī, originario de Murviedro. Transmitió de su padre y de Abū 1-Walīd al-Waqqašī, maestro este último que compartió con su padre. Véase al-Marrākušī, Dayl, VI, n. ${ }^{\circ} 627$.

${ }_{99}$ Apud al-Maqqaīi, Azhār, III, 106.

100 Véase Rodríguez Mediano, F., «Instituciones judiciales: cadíes y otras magistraturas», HEM, VIII-2, 176. 
el éxito como autor y como maestro del que gozó hasta su muerte. Que al final del párrafo en el que se hace referencia al incidente con Ibn al- ${ }^{\mathrm{A}} \overline{\mathrm{A}}$ ṣi, Ibn Jāqān especifique que al-Baṭalyawsī se dedicó a ciencias «nuevas» (hadīta) y «antiguas» (qadima), «sin que por conocerlas rebasara nunca el recinto de un precepto legal ni se desviara de ningún principio ni regla derivada de la sunna» ${ }^{101}$, indica que la presión contra Ibn al-Sỉd tuvo que ver precisamente con su interés por las ciencias no religiosas.

Del período valenciano procedería también la correspondencia con Ibn Jafāŷa ${ }^{102}$.

Respecto a una carta dirigida al gramático y literato sevillano $A b \bar{u}$ 1-Ḥasan 'Alī b. ${ }^{\mathrm{c}} \mathrm{Abd}$ al-Raḥmān b. Muḥammad Ibn al-Ajḍar al-Tanūjī ${ }^{103}$, al parecer por una disparidad de criterios sin mayor importancia, no me es posible precisar las fechas.

\section{La defensa de la religiosidad de al-Waqqaš̄}

Este episodio ha sido bien estudiado por M. Asín Palacios ${ }^{104}$. Al-Waqqašī (Huecas [Toledo] 408/1017-Denia 489/1095) fue cadí de Talavera. Después se trasladó a Valencia, donde medió ante Ibn Ŷạ̣hăf en la rendición de la ciudad al Cid. Durante el gobierno de este último ejerció el cargo de cadí y al final de su vida se trasladó a Denia, donde murió. Destacó en derecho, historia, filología y bellas letras. También se interesó por la teología, la filosofía y las matemáticas. Se le acusó de sostener ideas mu'tazilíes y de ateísmo; ello minó su prestigio como maestro.

Cierto día, cuenta Ibn al-Sīd, un alfaquí se presentó en su casa afirmando que al-Waqqašĩ era un impío por haber compuesto unos

\footnotetext{
101 Apud al-Maqqarī, Azhār, III, 138 e infra.

102 Véase Dīwān Ibn Jafäŷa (ed. Gazī, M.), El Cairo, 1960, 98-9. Véase también Tanbih, El Cairo, $1987^{2}, 11$ (estudio introductorio).

${ }^{103}$ Apud al-Maqqaīi, Azhār, III, 141-2. Ulema fallecido en 514/1120. Véase 'Iyāḍ, Gunya n. ${ }^{\circ}$ 79; Ibn Baškuwāl, Șila n. ${ }^{\circ} 920$.

104 En «La tesis de la necesidad de la revelación», especialmente 368-74 y 380-9. Asín edita y traduce la epístola que Ibn al-Sìd compuso sobre este asunto. En mi interpretación de este episodio sigo esa traducción y reproduzco entrecomillados algunos extractos de la misma.
} 
versos que fueron entendidos como una negación de la verdad de la revelación y una afirmación de la verdad de la filosofía:

Aflígeme [el pensar] que las ciencias de la humanidad son dos [tan sólo], que, si las aprendo, no tengo más [que aprender]:

Una ciencia cuya comprobación real es imposible, y una ciencia cuya verdad de nada sirve.

Ibn al-Sīd compuso una epístola en la que interpretaba benévolamente las palabras de quien seguramente había sido su amigo. Para ello expuso, aunque con una cierta pobreza de ideas según Asín Palacios, la tesis de la armonía entre las dos verdades a las que al-Waqqašī había supuestamente hecho alusión: revelación y pensamiento filosófico, resolviendo el problema a su manera. Se nos presenta así formando parte, tras Ibn Hazm ${ }^{105}$, de la cadena de precursores andalusíes de Averroes, quien dará su forma más acabada a esta teoría, siendo a partir de él asimilada por la escolástica cristiana. No es la única vez en que a nuestro personaje puede atribuírsele un papel de ese tipo. En su Kitāb al-tanbīh comprobamos que fue uno de los andalusíes pioneros en abordar la investigación en las causas de la discrepancia dogmática y doctrinal. Esta labor, a la que también contribuyó Abū Bakr Ibn al- ${ }^{\mathrm{c}} \mathrm{Arabī}{ }^{106}$, culminó en Averroes, restringida ahora al fenómeno de la divergencia entre los juristas.

De la lectura de la epístola se desprende que su redacción es posterior a la muerte de al-Waqqašì (489/1095), pues Ibn al-Sĩd se refiere a él con la expresión rahima-hu Allāh (Dios tenga piedad de él) y utiliza verbos en perfectivo. Asimismo, la expresión harrasa-hã Allāh (Dios la guarde), relativa a Valencia, indicaría que la ciudad ya no estaba en manos del Cid. Este indicio permite pensar que la epístola fue escrita después de 496/1102, en diacronía con el proceso contra al-Waqqaši - a menos que su religiosidad hubiera sido enjuiciada tras su muerte - y en sincronía con un hostigamiento hacia el propio Ibn al-Sĩd por parte de determinados alfaquíes valencianos.

En su apología, los argumentos de Ibn al-Sīd pueden resumirse como sigue: de las ciencias es mejor saber cuanto más mejor, a fin de

\footnotetext{
105 En ibid., 370, Asín Palacios no cae en la cuenta de la diferencia cronológica existente entre Ibn Hazm e Ibn al-Sīd y entre el de Badajoz e Ibn Țufayl. Este último error se repite también en Gómez Nogales, S., art. cit., 144.

${ }^{106}$ Con un al-Taljịs fì ușūl al-jiläf, que, al parecer, no se ha conservado.
} 
avanzar en el conocimiento de la verdad. No es incrédulo quien está al tanto de ideas impías, sino quien las profesa. Al-Batalyawsī atribuye la visión peyorativa de la filosofía al vulgo. Respecto a los filósofos y a su fama de agnósticos, Ibn al-Sīd distingue entre los auténticos y los falsos. «El filósofo auténtico es aquél que huye de los deleites sensuales, que ama el bien y a los que lo practican, que odia el mal y a los que lo hacen, que desprecia las cosas de acá abajo, que pone en la vida futura la meta de todos sus anhelos y se somete al cumplimiento de las leyes [reveladas]. El falso filósofo es el que hace todo lo contrario». La consagración a la filosofía no puede llevar nunca a la negación de las leyes reveladas ni al abandono de la adquisición de las virtudes ${ }^{107}$. Ibn al-Sīd efectúa una definición parcial, en la que sólo se destaca la faceta moral del filósofo, el cual, según Arnáldez, se distingue además por el uso de un determinado vocabulario técnico, por el cultivo de la lógica y por el estudio de la ciencia natural, la metafísica y la teología ${ }^{108}$. Tal forma de presentar al filósofo constituía un contrapunto a la medida de quienes pensaban que los filósofos eran hombres de pasiones ( $a h l a l-a h w \bar{a})$, es decir, que siguen su propio juicio y que son diametralmente opuestos a aquellos que siguen una revelación (arbāb diyāna) ${ }^{109}$.

Dice Ibn al-Sīd que consiguió convencer a su interlocutor. Después realiza la siguiente observación: «y [mi amigo] se marchó; pero yo me quedé luego arrepentido de haber mantenido con él aquella conversación y de haberme metido a hablar de cosas que ninguna necesidad tenía de haber tratado». Evidentemente Ibn al-Sīd no se estaba arrepintiendo en absoluto de lo que había escrito, pues en caso contrario no lo hubiera hecho. Lo que pretendía era neutralizar ulteriores suspicacias con respecto a su persona, mostrando su empatía con la corriente que recelaba del kaläm sin rechazarlo absolutamen-

\footnotetext{
$107 \mathrm{La}$ «adquisición de las virtudes» (al-iktisāb bi-l-faḍa'il) expresa la postura de los teólogos ašcaríes intermedia entre los partidarios de la predestinación y los del libre albedrío: el hombre no crea sus propios actos, como opinaban los segundos, sino que Dios los crea, como opinaban los primeros, pero el hombre los «adquiere», es decir, elige entre ellos haciéndose responsable de su elección.

108 Véase $E R^{2}$, s.v. «Faläsifa» [Arnáldez, R.]. El autor reconoce, no obstante, la dificultad de dar una definición precisa del término.

109 Esta era, según Arnáldez, art. cit., 767, la opinión de al-Šahrastānī. En su acepción popular, faylasüf se aplicaba a los librepensadores e incrédulos, véase $E I^{2}$ s.v. «Faylasüfi [Goldziher, I.].
} 
te ${ }^{110}$. Y para terminar de poner a al-Waqqašĩ, y a sí mismo, a salvo de toda sospecha, al-Bațalyawsī recurre a la visión del personaje en sueños 111: «Aquella noche me dormí, preocupado el espíritu con lo que me había sucedido, y en sueños vi a al-Waqqašì, sentado conmigo en la mezquita aljama de Valencia ${ }^{12}$, junto a la alqibla, conversando conmigo y sonriéndose. Yo le refería lo que me había ocurrido acerca de él; él, a su vez, me decía algo y, en medio de su razonamiento, me recitó un famoso verso, que es del poeta Nahar ibn Tawsica al-Yašqurī:

Mientras vosotros os gloriáis de [tener por ascendientes a] Qays o Tamìm, el islam es mi padre y yo no tengo otro».

\section{Conclusiones}

En la primera mitad de su vida Ibn al-Sīd responde al prototipo del hombre de letras del siglo XI: una formación sólida en gramática, lexicografía, $a d a b$ y lecturas coránicas proporciona a nuestro personaje los medios con los que ganarse la vida, moviéndose de corte en corte como poeta oficial, como secretario y como lector coránico. Sus dotes poéticas, retóricas y dialécticas le permiten establecer relaciones con reyes, ministros y secretarios, a quienes acude para abrirse camino en la administración, o simplemente para encontrar asilo cuando se ve envuelto unas veces, sin quererlo, en las turbulencias políticas, y otras, en peligros de la vida palaciega que no pone mucho cuidado en evitar. De esta primera etapa no consta actividad en el campo de la enseñanza. No puede descartarse, sin embargo, que Ibn al-Sĩd hubiera comenzado ya a componer alguna de sus obras, además de la creación poética y de la correspondencia epistolar.

110 Respecto a la actitud de los ulemas del período almorávid frente al kalām, véase Fierro, M., «La religión», HEM, VIII-2, 466-8. Un ejemplo de esta postura intermedia entre la aceptación y el rechazo es la que, según su hijo, sostenía el cadí 'Tyād. Véase Serrano, D., «Los Banū 'Iyāạ, de la caída del imperio almorávid a la instauración de la dinastía nazarí» en Fierro, M. y Ávila, M.L., (eds.), EOBA, IX, Madrid-Granada, 1999, 363.

111 Ello reafirma la impresión de que al-Waqqašĩ había muerto ya cuando Ibn al-Sìd lo defiende por escrito.

112 Dónde también Ibn al-Sĩd enseñaba a sus alumnos. Véase al-Marrākušĩ, al-Dayl wa-l-Takmila, V-1 (ed. 'Abbās, I.) Beirut, 1965, n. ${ }^{\circ} 455$, p. 230 
¿Adquirió Ibn al-Sīd sus conocimientos en filosofía con maestros o lo que sabía lo aprendió leyendo y discutiendo con otros? Me inclino por lo segundo. La mayoría de los especialistas no considera su pensamiento un sistema filosófico. Su verdadero genio hay que buscarlo en la lengua y en la filología, disciplinas que le situaron en un lugar de privilegio desde el que pudo realizar contribuciones notables a ciencias como el hadiz y el fiqh. Se duda de que su figura represente la etapa inmediatamente anterior al apogeo de la filosofía islámica andalusí; considerarle un filósofo en toda regla sería exagerado, e injusto calificarle de mero aficionado. El alcanzado por Ibn al-Sīd fue un nivel intermedio de conocimiento que, representativo o no, le permitió exponer una teoría emanatista de la creación - original en virtud de su filiación pitagórica ${ }^{113}$ - y formular por primera vez en al-Andalus la tesis de la conciliación entre el credo y la razón. Asimismo hay que tener en cuenta que Ibn al-Sïd se anticipó a Averroes al intentar racionalizar el problema de la discrepancia. Las diferencias entre ambos son notables: Ibn al-Sīd aparece flojo en materia de fiqh, impreciso en teología, muy sólido en cuestiones léxicas, gramaticales y de tradición. El verdadero interés del Tanbih radica en la manera en que, como el adì que era, su autor combina diferentes disciplinas (lengua-fiqh-teología-hadiz) para crear método. Probablemente hayamos de poner la originalidad atribuible a esta obra, y su interés, en proporción directa con la dificultad de clasificarla adecuadamente.

No puede afirmarse con contundencia que Ibn al-Sīd marcó la historia de la filosofía islámica andalusí, pero sí que, por el contrario, la filosofía marcó la historia de Ibn al-Sīd. Curiosamente, y teniendo en cuenta que ha pasado a la posteridad como un gramático de primera, no lo encontramos allí donde más pujanza alcanza el estudio de la lengua, sino que aparece en cortes en las que se favorecen las «ciencias de los antiguos». Como todos los cambios políticos a gran escala, la conquista almorávid altera el mapa de la actividad cultural andalusí e Ibn al-Sĩd no tiene más remedio que intentar acomodarse a esta nueva situación. No parece haber tenido problemas para encontrar trabajo en la nueva administración, pero sí para mantenerlo. Las causas po-

\footnotetext{
113 Aparte del trabajo de Asín Palacios véase ahora también J. Cobos, «Evolución del concepto del número: El Número en el «Libro de los Cercos» de Abū Muhammad Abdallah B. Muhammad Ibn al-Sīd al-Bațalyawsī» en F. Díaz Esteban (ed.), Bataliús. El Reino Taifa de Badajoz. Estudios, Madrid, 1996, 63-76.
} 
drían tener que ver con la fuerte personalidad de alguien que, lleno de recursos y acostumbrado a caminar sobre arenas movedizas, se permite el lujo de no ser prudente. Vuelve entonces a probar suerte en lo que queda de territorio independiente en al-Andalus e incluso ante gobernantes no musulmanes.

La definitiva instalación del poder almorávid en Levante tiene efectos perceptibles en la vida de Ibn al-Sīd. Su interés por las ciencias profanas y quizá la huida de Córdoba parecen estar en el origen de un intento de procesamiento. Sería entonces cuando decide redactar la epístola en favor de al-Waqqašī, para defenderse a sí mismo y a los «filósofos auténticos», clase a la que está convencido de pertenecer y cuyo papel al lado de los ulemas tradicionales en la búsqueda de la verdad intenta legitimar. ¿Defendió Ibn al-Sỉd la figura de al-Waqqašī, o la utilizó? Ambas cosas. En cualquier caso al-Waqqašī, una vez muerto, tenía poco que perder y al-Bațalyawsī, al menos, tuvo la valentía de no esquivar el recuerdo de su amistad.

Si en la época de las taifas el recelo de los ulemas más conservadores respecto a las ciencias empíricas y racionales topó con los gustos del poder político, en el período almorávid tal barrera desaparece. Todo aquel que se dedicaba al estudio de la filosofía, se queja Ibn al-Sīd, era acusado de herejía e infidelidad. Debido a la censura contra la filosofía, un personaje como Mālik b. Wuhayb - que antes de dedicarse a las ciencias religiosas y destacar en hadiz había cultivado la lógica - dejó muy poco escrito sobre este último tema y llegó a sufrir atentados contra su vida. Sin embargo, lo encontramos entre los consejeros de ${ }^{c} \mathrm{Alī} b$. Yùsuf, quien no se habría conformado con el asesoramiento exclusivo de esos alfaquíes, a los que, se dice, era tan afecto ${ }^{114}$. Y si sabemos que los tan vituperados alfaquíes no formaban un grupo monolítico, lo mismo puede decirse de los filósofos y los científicos ${ }^{115}$. Así pues, no puede hablarse de persecución sistemática, pero sí de un cierto hostigamiento contra los partidarios de las ciencias racionales que, en cualquier caso, para algunos como Ibn al-Sīd e Ibn Wuhayb no terminó en marginación social o política. Sin embargo, en adelante, el sabio tiene que andarse con más cuidado, tomar ciertas precauciones y darse un aire más religioso. $\mathrm{Y}$ es así que, para

114 Véase Dunlop, D.M., art. cit., 100-3 y Marín, M., «La actividad intelectual», 529-30. Sobre Ibn al-Imām al-Saraqusțī, secretario de Tamīm b. Yūsuf b. Tãšufīn y amigo de Ibn Bāŷŷa, véase Fierro, M., «La religión», HEM, VIII-2, 438.

115 Tal conclusión puede extraerse de la lectura del citado artículo de Dunlop. 
acentuar su más profundo apego a la ortodoxia, Ibn al-Sīd ve la necesidad de insistir en la armonía entre pensamiento filosófico y revelación y de echar mano de sus dotes como tradicionista y alfaquí; a ello debemos tanto la llamada «defensa de al-Waqqašì como la composición del Kitāb al-tanbïh. Pero el hecho de que en este último critique a los alfaquíes sugiere que, aunque prefirió adaptarse antes que abandonar al-Andalus, no estaba dispuesto a traicionarse. Es evidente, sin embargo, que el ambiente se tornó desfavorable a los estudios filosóficos y, aunque no supuso su desaparición, tuvo que afectarlos negativamente. Y de hecho no he encontrado noticias acerca de la transmisión del Kitāb al-hadā'iq entre los discípulos musulmanes de Ibn al-Sìd, ni acerca de la composición de obras posteriores del mismo signo que fueran más allá de la mera autodefensa. De esta última batalla, paradójicamente, salió perjudicado como filósofo, pero fortalecido como ulema, a juzgar por su éxito entre los estudiantes de la época y por la composición de numerosas obras. La enseñanza se convierte a su vez en un escudo. Frente al ejercicio de cargos administrativos y al cultivo de la poesía cortesana, garantiza - seguramente porque las clases eran remuneradas - la independencia con respecto a los vaivenes de la política.

Zaragoza, Valencia, Alejandría y La Meca aparecen como los centros a partir de los cuales la obra de Ibn al-Sīd fue transmitida a Europa y a Oriente. Como no era raro entre los dedicados al saber en todo el Islam medieval, Ibn al-Sĩd alcanzó la edad de setenta y cinco años, muriendo en Valencia a mediados de Raŷab de 521/1127. Si la tuvo, no se han conservado noticias acerca de su descendencia.

\section{Apéndices}

\section{Relación de maestros 116}

1. Abū l-Hasan 'Alī b. Ahmad b. Hamdūn al-Muqri' al-Bațalyawsī, conocido como Ibn al-Latīniyya. Almocrí que estudió con otro almocrí, Abū 'Umar al-Muqri'. Murió en Badajoz en 466/1074 ${ }^{117}$.

2. Abū l-Ḥasan 'Alī b. Muhammad b. al-Sīd al-Bațalyawsī. Hermano de ${ }^{c} A b d$ Allāh b. Muhammad. También gramático y lexicógrafo. De la gente

\footnotetext{
116 En la localización de personajes, tanto en el caso de los maestros como de los discípulos, me han sido de gran ayuda las diferentes nóminas aparecidas hasta el momento en la serie $E O B A$.

117 Véase Ibn Baškuwāl, Șila (ed. al-Abyārī, I.), n. 901.
} 
de Badajoz. Era conocido como al-Sābiq al-Jayțāl. Transmitió de Abū Bakr b. al-Gurāb de Badajoz y del también pacense Ảbū ${ }^{\mathrm{c}} \mathrm{Abd}$ Allāh Muhammad b. Yūnus (instructor de al-Muzaffar Ibn al-Aftas y de sus hijos), y otros. Enseñó a su hermano numerosas obras de $a d a b$. Ibn Bassām se refiere a él como Abū l-Hasan al-Kātib, de donde se desprende que en algún momento de su vida ejerció como secretario. Murió en Calatrava, donde había sido

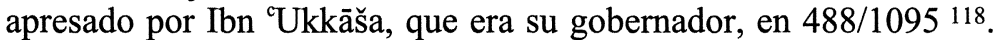

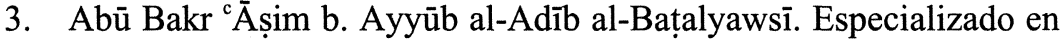
poesía (m. 494/1101) ${ }^{119}$.

4. Abū ${ }^{\mathrm{c}}$ Alī al-Husayn b. Muhammad al-Gassānī al-Ŷayyānī. Destacado tradicionista cordobés, discípulo de Ibn ' $\mathrm{Abd}$ al-Barr, de Abū 1-Walīd al-Bāŷī y de al-'Uddri. No viajó a Oriente ${ }^{120}$.

5. Abū Sa ${ }^{c} \bar{i}$ al-Warrāq. Literato del que al-Humaydị y al-Dabbī transmiten sólo una anécdota según la cual llevó a cabo la peregrinación a La Meca. Según al-Humaydī, lo mencionó Ibn Hazm ${ }^{121}$.

Los editores del Kitāb al-tanbīh (véase Apéndice 3, n. ${ }^{\circ} 15$ ) citan, sin mencionar fuentes, otros maestros cuya relación con nuestro personaje es incierta, pues podría tratarse de una confusión con su hermano ${ }^{\circ} \mathrm{Ali}$. Esos maestros son Abū l-Faḍl al-Wazīr Muhammad b. ${ }^{c} \mathrm{Abd}$ al-Wāhid al-Tamīmī al-Bagdādī 122, 'cAbd al-Dā'im b. Marzūq/Marwān Ibn Ŷabr al-Qayrawānī ${ }^{123}$, 'Uțmān b. Sa ${ }^{\mathrm{C}} \mathbf{i} d$ al-Anșārī y ${ }^{\mathrm{C}}$ Alī b. Jalaf al-Dānī 124 .

118 Véase Ibn Baškuwāl, Sila n. ${ }^{\circ}$ 910; Ibn Bassām, Dajīra, III, 892; al-Qifțī, Inbāh al-ruwāt, II, 307; al-Șafadī, Wäfi, Wiesbaden, 1962, XXII, 110; al-Suyūṭī, Bugya, II, 189 n. ${ }^{\circ}$ 1765; Yāqūt, $M u^{c} \hat{y} a m$ al-udabā' (ed. Margoliouth, D.S.), El Cairo, 1938, XV, 56 y Ávila, M.L., «La Sociedad», HEM, VIII-1, 320.

119 Véase Ibn Baškuwāl, Sila n. ${ }^{\circ} 969$ y al-Suyūțī, Bugya, II, 24.

120 Véase 'Iyād, Gunya, n. ${ }^{\circ} 48$; Ibn al-Abbār, Mu' ${ }^{c} \hat{y} a m$ (ed. al-Abyārī, I.), El Cairo-Beirut, 1989, n. 67 e Ibn Farhūun, Dïbäây, I, 332-3.

121 Véase al-Humaydī, Ŷadwat al-muqtabis (ed. al-Abyārī, I.), Beirut, 1984, II, 268 n. 938 y al-Dabbì, Bugya, II, 701 n. ${ }^{\circ} 1534$. En su artículo «Enseñanzas de Ibn Hazm en la 'Ŷadwat al-Muqtabis' de al-Humaydī», Al-Andalus 29 (1964) 147-78, E. Terés no menciona a $\mathrm{Abū} \mathrm{Sa}{ }^{c} \bar{i} d$ al-Warrāq entre los más importantes compañeros de Ibn Ḥazm.

122 Originario de Bagdad, se instaló en Toledo, donde murió en 454-5/1063. Se le acusó de transmitir mentiras. Era un poeta, protegido de al-Ma'mūn. Véase Ibn Baškuwāl Sila n..$^{\circ} 1194$; al-Humaydī, Ýadwa n..$^{\circ} 105$ y al-Dabbī, Bugya, n. 210.

${ }^{123}$ Almocrí y filólogo, maestro de ${ }^{\mathrm{c}}$ Alì b. al-Sīd con el que estudió Siqt al-zand de al-Ma arrī. Se instaló en Almería y había sido discípulo de Ibn ${ }^{\mathrm{c}} \mathrm{Abd}$ al-Barr. Murió en Toledo en 472/1079. Véase Ibn Baškuwāl, Șila n. ${ }^{\circ} 847$; al-Dabbī, Bugya n. ${ }^{\circ} 1131$ y Peña, S., Ma arrī según Bațalyawsī. Crítica y Poética en al-Andalus, siglo XI, Granada, 1990, 158

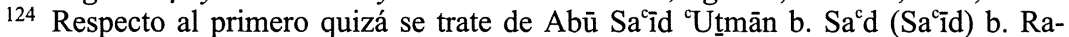
madān al-Anșārī, del que sólo se sabe que fue discípulo de Ảbū 1-Walīd al-Bāŷî. Véase al-Marrākušì, Dayl, V-1 n. ${ }^{\circ} 263$. Respecto al segundo, los diccionarios biográficos recogen la biografía de un tal Abū l-Ḥasan ${ }^{\mathrm{c} A l i ̄ ~ b . ~ J a l a f ~ b . ~ ' U m a r ~(a l-H ̣ a s a n) ~ b . ~ H i l a ̄ l, ~ c u y a ~ c r o-~}$ nología (m. ca. 570/1174) haría pensar más en un discípulo que en un maestro de Ibn al-Sìd. 


\section{Relación de discípulos}

Se trata de una relación no exhaustiva, sino meramente orientativa.

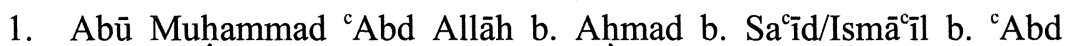
al-Rahmān, conocido como Ibn Mawŷuwāl al- ${ }^{\mathrm{A}}$ Abdarī al-Balansī (m. 566/1171). Alfaquí, tradicionista y almocrí de la gente de Valencia. Su principal maestro fue Ibn al-Sìd. Después se instaló en Sevilla, donde murió. Allí Abū Bakr Ibn al- ${ }^{\mathrm{c} A r a b i ̄ ~ d e s t a c o ́ ~ e n t r e ~ s u s ~ m a e s t r o s . ~ I b n ~ J a y r, ~ A b u ̄ ~}$ 1-Qāsim al-Qanțarī y Abū l-Qāsim al-Samātī transmitieron de él algunas obras de al-Batalyawsīi ${ }^{125}$.

2. Abū Muhammad 'Abd Allāh b. Muhammad b. Jalaf b. Sa āda al-Aṣbahī. Alfaquí, almocrí y tradicionista de Denia. Vivió en Alejandría, donde se instaló (nāzilan) en la madrasa ádiliyya. Murió después de 570/1174 ahogado en el mar, como mártir. Ibn al-Ŷazarī refiere que el $n .^{\circ} 5$ leyó ante este ulema lo que este último había leído ante Ibn al-Sĩd, con toda probabilidad en Valencia 126.

3. Abū Muhammad 'Abd al-Haqq b. 'Atiyya (481/1088-541/ 1146). Ibn al-Sīd le concedió por escrito la licencia para transmitir su Kitāb al-iqtidāa ${ }^{127}$.

4. Abū 1-Hasan/Husayn ${ }^{\mathrm{C} A b d}$ al-Malik b. Muhammad b. Hišām al-Qaysī, conocido como Ibn al-Tallā al-Jațî̉. De la gente de Silves, alfaquí experto en hadiz, en $a d a b$ y en lexicografía, m. 551/1156. Transmitió de Abū ${ }^{\mathrm{c}} \mathrm{Alī}$ al-Șadafĩ y en Levante habría estudiado también con Ibn al-Sīd. Ocupó la judicatura de Monchique (Hiṣn Marŷīq) durante la rebelión de Ibn Qasī. Asimismo ejerció el cargo de jațīb de la aljama de Silves 128 .

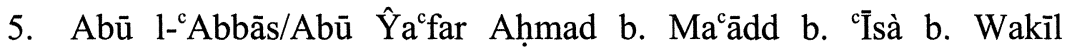
al-Tuŷīīi al-Wāfĩ al-Mālikī, conocido como Ibn al-Uqlīšì. Nacido en Denia, estudió en Valencia. En 542/1147 llevó a cabo la peregrinación, muriendo en el camino de regreso, en Qūs (Alto Egipto) 574/1147 ó 584/1154 ó 550/1155. Autor del Šarh asmā' Allāh al-husnà, del Šarh al-bāqiyāt al-șälihạat y del Kitāb al-naŷm min kaläm sayyid al-carab wa-l- ${ }^{c} a \hat{y} a m{ }^{129}$.

6. Abū l-'Abbās Ahmad b. 'Abd al-'Azīz b. al-Fudayl b. al-Jali ${ }^{\mathrm{c}}$ al-Anșārī al-Warrāq conocido como al-Qibsī (con la b romance $=p$ ). Origina-

\footnotetext{
125 Véase Ibn al-Abbār, Takmila (ed. Harrās, ${ }^{\mathrm{C} A . S .), ~ I I, ~ 268-9 ~ n . ~}{ }^{\circ} 779$.

126 Véase Ibn al-Abbār, Takmila (ed. Harrās, 'A.S.), III, 271 n. ${ }^{\circ} 786$. n. ${ }^{\circ} 109$

127 Véase Fihris Ibn 'Atịyya (ed. Abū l-Aŷfān, M. y al-Zāhī, M.), Beirut, 1980, 109

128 Véase al-Dabbī, Bugya, n. ${ }^{\circ} 1058$; Ibn al-Abbār, Takmila (ed. Harrās, ${ }^{\mathrm{C}} \mathrm{A} . \mathrm{S}$.), III, n. ${ }^{\circ} 197$ y El Hour, R., «El Algarbe en época almorávide: Aspectos políticos y jurídicos», Actas I Curso sobre la Península Ibérica y el Mediterráneo durante los siglos XI y XII (27-30 de julio de 1996), Aguilar de Campoo (Palencia), 1998, 45.

129 Véase Brockelmann, C., GAL, I, 370.
} 
rio de Šuriyyūn, vivió en Valencia. Estudió $a d a b$ y lengua árabe con Ibn al-Sīd. Murió asesinado en Sevilla en 572/1176 130.

7. Abū Bakr Ahmad b. Abī l-Muțarrif ${ }^{c} A b d$ al-Rahmān b. Ahmad b.

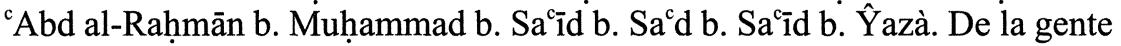
de Valencia. Destacó en la ciencia del reparto de las cuotas hereditarias y en aritmética. Estudió $\left(\operatorname{sami}^{c} a\right)$ con Ibn al-Sīd, pero éste no le concedió la $i \hat{y} \hat{a} z a$. Curiosamente, sin embargo, "compuso una gran [cantidad de obras sobre] ciencia hasta el punto de convertirse en único en la transmisión a partir de al-Batalyawsī»; murió en 583/1187 131 .

8. Abù l-'Abbās Aḥmad b. Mālik b. Marzūq/Marwān. Tradicionista y alfaquí de Tortosa, donde ejerció el cadiazgo. Cuando fue tomada por los cristianos en 543/1148, se marchó a Valencia, m. 553/1158 132.

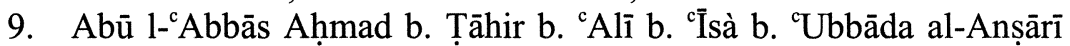
al-Jazraŷi. Originario de Valencia y nacido en Denia. Tradicionista y alfaquí. Ocupó el cargo de mušãwar en Denia. Renunció al cadiazgo de la ciudad. Según el cadí 'Iyāọ, de quien fue maestro, tendía tanto en fiqh como en hadiz hacia el literalismo (zähir), m. 532/1138 133 .

10. Abū 1-'Abbās Aḥmad b. 'Uțmān b. Hārūn al-Lajmī. Estudió en Granada. Ibn al-Sīd le concedió î̀äza para transmitir el Kitāb al-tanbih en 515/1121, obra que este ulema debió enseñar en Alejandría, donde recaló en el transcurso de su viaje de peregrinación ${ }^{134}$.

11. Abū Ŷa ${ }^{c}$ far Ahmad b. Ŷubayr b. Muhammad b. Ŷubayr Ibn Muhammad b. Marwān b. 'Abd al-Salām b. Marwän b. 'Abd al-Salām b. Ŷubayr al-Kinānī. De la gente de Valencia. Poeta y secretario, que aprendió adab con Ibn al-Sīd. Fue visir de Abū ${ }^{\mathrm{C}} \mathrm{Abd}$ al-Malik Marwān b. ${ }^{\mathrm{c}} \mathrm{Abd}$ al- ${ }^{\mathrm{C}} \mathrm{Azīz}$ cuando se rebeló contra los almorávides en Valencia. Murió en 552/1157 135 .

12. Ibrāhīm b. Muhammad b. Ibrāhīm b. Muhammad b. Yūsuf al-Anșārī al-Jazraŷî, conocido como al-Tuțịìi. Fue también discípulo de Abū Bakr Ibn al- ${ }^{\mathrm{C}}$ Arabī. Llevó a cabo la peregrinación, pasando al parecer por Alejandría, aunque Ibn al-Abbār no da mucho crédito a la fuente de la que toma esta noticia 136 .

13. Abū Isḥāq Ibrāhīm b. Muhammad al-Mutqin Ibn Ibrāhīm al-Lajmī al-Sabtī, m. después de 570/1174. Enseñó el Tanbīh en Alejandría en 523/1129. Lo había estudiado en Valencia, con su autor, en Ŷūmādà l-ūlà

130 Véase Ibn al-Abbār, Takmila (ed. al-Abyārī, I.), I, n. ${ }^{\circ} 207$.

131 Íbidem, I, n. ${ }^{\circ} 224$.

132 Véase Ibn 'Abd al-Malik al-Marrākušī, Dayl (ed. Bencherifa, M.) Rabat, 1984, I/2, n. ${ }^{\circ} 816$ e Ibn al-Abbār, Takmila (ed. al-Abyārī, I.), I, n. ${ }^{\circ} 172$.

${ }^{133}$ Véase 'Iyād, Gunya, 118 n. ${ }^{\circ} 43$ e Ibn al-Abbār, Takmila (ed. al-Abyārī, I.), I, n. ${ }^{\circ} 127$.

${ }^{134}$ Véase Ibn al-Abbār, Takmila (ed. al-Abyārī, I.), I, n. ${ }^{\circ} 191$ y al-Kattān̄i, Fihris al-fahāris, (ed. 'Abbās, I.), Beirut, 1986, II, 1050-1 n. ${ }^{\circ} 591$.

135 Véase Ibn al-Abbār, Takmila (ed. al-Abyārī, I.), I, n. ${ }^{\circ} 169$.

136 Íbidem, I, n. ${ }^{\circ} 403$. 
516/1122. En Alejandría lo aprendió con él el cadí y alfaquí Abū Muḥammad ${ }^{c} A b d$ Allāh b. al-Qādī Abī l-Faḍl ${ }^{c} A b d$ al-Rahmān b. Yahyà b. Ismācīl al-'Uțmānī. En la ciudad egipcia İbn Ibrāhīm al-Lajmī fue discípulo de Abū 1-Tāhir al-Silafĩ. Estuvo también en La Meca, donde podría haber continuado la enseñanza del Tanbih, pues en la cercana Medina se conservan dos copias de la obra 137 .

14. Abū Ishāq Ibrāhīm b. Yũsuf b. Adham b. ${ }^{c} A b d$ Allāh b. Bādīs Ibn al-Qā'id al-Qā'idī al-Hamzī al-Wahrānī, conocido como Ibn Qurqūl (Almería 505/1111-Fez 569/1174). Alfaquí, adīb, häfiz y tradicionista, nieto por parte de madre de Abū l-Qāsim Ibn Ward. Estudió con el maestro en Valencia. Fue también discípulo de Abū l- ${ }^{\mathrm{c}} \mathrm{Abbās}$ Ibn al- ${ }^{\mathrm{c}}$ Arīf y de Abū Bakr Ibn al- ${ }^{\mathrm{C}} \mathrm{Arab}{ }^{1}{ }^{138}$.

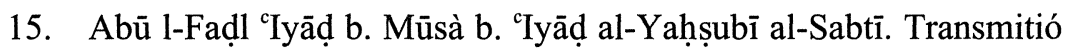
de Ibn al-Sīd por $\dot{i} \hat{y} \bar{a} z a{ }^{139}$.

16. Abū l-Qāsim Jalaf b. ${ }^{\mathrm{C}}$ Abd al-Malik Ibn Baškuwāl. Transmitió del maestro a partir de la $i \hat{y} \bar{a} z a$ concedida por éste, más de una vez ${ }^{140}$.

17. Abū ${ }^{\mathrm{c}} \mathrm{Abd}$ al-Malik Marwān b. ${ }^{\mathrm{c}}$ Abd Allāh b. Marwān al-Balansī. Cadí de Valencia y $r a^{\prime} \bar{s} u$-hā, m. 578/1182 ${ }^{141}$.

18. Abū Tāhir Muhammad b. Yahyà b. ${ }^{\circ} A b d$ Allāh b. Yūsuf b. ${ }^{c} A b d$ Allāh al-Tamìmī. Literato, poeta y gramático zaragozano asentado en Córdoba, m. 538/1143. Autor de Maqāmāt. Compañero de Ibn Baškuwāl, transmitió a éste un poema de Ibn al-Sĩd que había aprendido recitándolo ante su autor en la mezquita aljama de Córdoba ( $\left.\hat{y} \bar{a} m i^{c} Q u r t u b a\right)$. Es el mismo poema que transcribe el cadí 'Iyāọ en su Gunya. De aquí se desprende que en Córdoba Ibn al-Sīd se dedicó también a la enseñanza ${ }^{142}$.

19. Abū ${ }^{\mathrm{c}} \mathrm{Abd}$ Allāh Muhammad b. Yūsuf/Yahyà b. Sa āda al-Šātibī al-Mālikī al-Mursī al-Zaynabī. Tradicionista y alfaquí de la gente de Murcia que vivió en Játiva (496/1102-564/1169 ó 565/1170). El más importante de sus maestros fue Abü ${ }^{\mathrm{c}} \mathrm{Alī} \mathrm{al-Ṣadafī,} \mathrm{de} \mathrm{quien} \mathrm{era} \mathrm{yerno.} \mathrm{Estudió} \mathrm{también} \mathrm{en}$ el Garb al-Andalus (Córdoba esencialmente) e hizo la rihla a Oriente. Parece que Ibn al-Sīd le concedió $i \hat{y} \bar{a} z a$ para transmitir sus obras por escrito an-

137 Íbidem, I, n. ${ }^{\circ} 459$ (gurabā̄); Tanbīh, El Cairo, 1982², 1 y fichero Historia de los Autores y Transmisores de al-Andalus, proyecto en curso dirigido por M. Fierro, capítulo sobre fiqh.

${ }_{138}$ Véase Ibn al-Abbār, Takmila (ed. al-Abyārī, I.), I, n. ${ }^{0} 394$.

139 Véase Gunya n. ${ }^{\circ} 61$ y Hermosilla, M.J., «Los maestros andalusíes en la Gunya del cadí 'Iyāḍ (476-544/1084-1149)», Anuario de Filología, 7 (1981), 314, n. ${ }^{\circ} 5$.

140 Véase Ibn Baškuwāl, Șila (ed. al-Abyārī I) n. ${ }^{\circ} 649$ y Puente, C. de la, «La transmisión de hadiz y de tradiciones ascéticas en al-Andalus en el siglo VI/XII a través de la biografia de Ibn Baškuwāl» en Marín, M. y de Felipe, H. (eds.), EOBA, VII, Madrid, 1995,243, n. $^{\circ} 45$

141 Véase Ibn al-Abbār, Takmila (ed. Harrās, ${ }^{\mathrm{C} A . S}$.), III, n. ${ }^{\circ} 483$.

142 Véase Ibn Baškuwāl, Șila (ed. al-Abyārī, I.) n. ${ }^{\circ} 1229$ y Puente, C. de la, «La transmisión de hadiz», 241, n. $^{\circ} 28$. 
tes de 520/1126, probablemente desde Valencia. Fue nombrado mušāwar y jațīb en Murcia, y cadí de Játiva, donde murió ${ }^{143}$.

20. Abū Bišr/Abū l-Hasan o Abū l-Husayn Țāhir b. 'Abd al-Rahmān b. Sa ${ }^{\mathrm{i}} \mathrm{d}$ b. Ahmad al-Anșārī. De Denia, donde murió después de 540/1145. Conocido como Ibn Subayța. Es, según Ibn al-Abbār, uno de los más importantes discípulos de al-Batalyawsī. Enseñó lengua árabe y literatura. También se dedicó a la astrología judicial ( ${ }^{c} i l m$ al-niȳāma) ${ }^{144}$.

21. Abū Hafṣ cUmar b. Muhammad b. Wāŷib al-Qaysī al-Balansī. De una familia originaria de Beja. Ejerció como sạhib al-aḥkām y como mušăwar, el primero de los cargos mientras su padre era cadí de Valencia y Játiva, el segundo en Valencia. Asimismo ocupó el cadiazgo de Denia durante los primeros meses del emirato de Abū ${ }^{\mathrm{c}} \mathrm{Abd}$ Allāh $\mathrm{b}$. Sa ${ }^{\mathrm{c}} \mathrm{d}$. Alfaquí, muftí, memorizador de cuestiones jurídicas (masā'il), experto en sentencias (bașīan fì l-ahkām) y en ra'y, enseñó fiqh en su ciudad natal. No destacó en hadiz. Murió en Valencia en 557/1162 ${ }^{145}$.

\section{Relación de sus obras 146}

1. Fahrasa. Fue transmitida a Ibn Jayr por los alfaquíes Abū l-Husayn cAbd al-Malik b. Muhammad b. Hišām al-Qaysī y Abū Muhammad ${ }^{\mathrm{c}} \mathrm{Abd}$

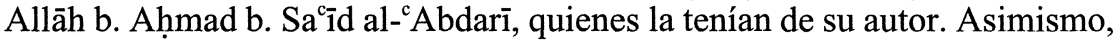
fue una de las fuentes en las que se basó Ibn al-Abbār ${ }^{147}$. Desgraciadamente parece perdida. La composición de esta obra indicaría que Ibn al-Sīd tuvo muchos más maestros de los que hoy conocemos.

2. Kitäb al-hadā'iq o «Libro de los cercos» ${ }^{148}$, obra en la que el autor expone una jerarquía de la emanación de los principios del ser a partir del uno a la manera neoplatónica y plotiniana, con reminiscencias neopitagóricas. Esta jerarquía emanatista está, en opinión de Asín Palacios, muy influi-

143 Véase Ibn al-Abbār, Takmila (ed. Harrās, ${ }^{\mathrm{C}}$ A.S.), III, n. ${ }^{\circ} 98$.

144 Íbidem I, n. ${ }^{\circ} 942$ y al-Marrākušì Dayl, IV, n. ${ }^{\circ} 281$.

145 Véase Ibn al-Abbār, Takmila (ed. Harrās, ${ }^{\circ}$ A.S.), III, n. ${ }^{\circ} 387$. Otros discípulos en ibid., I, nos. 641, 846, 860, 1221, 1257, 1306 (este discípulo también mantuvo una polémica con Ibn Jalașa); II, nos. 23, 63, 89, 101, 116, 119, 121, 122, 135, 139, 160, 748; III, nos. 185, 240, 267, 292, 353, 389 (min akäbir aṣhāb al-Bațalyawsī), 470, 498, 516, 526 y IV, nos 56, 100, 128, 269, 338, 368, 506, 509, 584.

${ }_{146}$ Agradezco a A. Sidarus sus observaciones acerca de las traducciones y ediciones de las obras de Ibn al-Sīd.

147 Véase respectivamente Fahrasat Ibn Jayr (ed. al-Abyārī, I.), El Cairo-Beirut, 1989, II, 566, n. ${ }^{\circ} 1303$ y Takmila (ed. al-Abyārī, I.), I, n. ${ }^{\circ} 475$.

${ }_{148}$ Editada y estudiada por Asín Palacios, M., «Ibn al-Sĩd de Badajoz y su «Libro de los cercos»; (ed. al-Kawtarī, Z.) El Cairo, 1946; (trad. italiana con reedición del texto de Asín por Jevolella, M.) Milán, 1984; (trad. portuguesa a partir de la de Asín, por Borges Coelho, A., Portugal na Espanha Arabe, Lisboa, 1989², I, 154-99). 
da por las Cartas de los Hermanos de la Pureza/Puros. Parece que se escribió con el fin de iniciar al público profano en las doctrinas de los filósofos. Por otra parte, representa uno de los primeros pasos que se dieron en al-Andalus en la formulación de la tesis de la armonía entre credo islámico y pensamiento griego ${ }^{149}$.

3. Kitāb al-hulal fí abyāt al-ŷumal. Comentario de los versos citados por al-Zaŷŷâŷ̃ en su obra gramatical Kitāb al-ŷumal ${ }^{150}$. Editado en El Cairo 1979 por M. Imām. El comentario de Ibn al-Sīd se une a los de Sa ${ }^{\top} \bar{i} d \mathrm{~b}$. ${ }^{\mathrm{C}} \mathrm{I}$ sà $(\mathrm{m}$. ca. 469/1067) y Jalaf b. Fath b. Ŷūīi (m. después de 433/1041), quienes son definidos por los biógrafos como lógicos 151 .

4. Al-Intișār mimman ${ }^{c}$ adala ${ }^{c}$ ani l-istibșār. Refutación en respuesta a los fallos que Abū Bakr Ibn al-'Arabì afirmaba haber encontrado en el Šarh Dīwān Abi l- ${ }^{c} A l \bar{a}^{\prime}$ al-Ma ${ }^{c}$ arrì y en al-Iqtidāa (v. infra). En al-Intịsār Ibn al-Sĩd ponía de manifiesto, cuestión por cuestión, los errores que Ibn al- ${ }^{\mathrm{C}}$ Arabi había cometido al criticarle ${ }^{152}$. Esta obra fue transmitida por ${ }^{c}$ Umar b. Muhammad b. Ahmad b. 'Udays al-Quḍācīe discípulo de Ibn al-Sĩd. Ibn al-Abbār afirma haber encontrado la mencionada transmisión

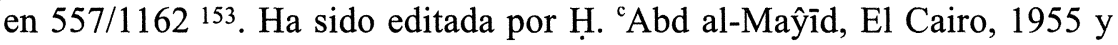
1996.

5. Al-Iqtidāa fi šarh adab al-kuttāb. Comentario del Adab al-kuttāb o "Manual para la instrucción de los secretarios" de Ibn Qutayba en el que, según Asín Palacios ${ }^{154}$, se presta una singular atención al prólogo de la obra original y dentro de éste, a los términos de tipo filosófico. Editado en Beirut, 1901, Beirut 1973 y luego en El Cairo, s.d. por M. al-Saqqā' y H. ' Abd al-Maŷīd, parece que desgraciadamente este comentario no aporta datos útiles para el estudio de la kitāba en al-Andalus, aunque ello sólo podrá asegurarse tras un estudio detenido del Iqtidāa. Al comentario de Ibn al-Sīd, que es el que más fama adquirió, hay que unir otros como el de al-Hasan b. Muḥammad b. Yahyyà b. 'Ulaym, también pacense ${ }^{155}$. Muḥammad b. Jalaṣa ${ }^{156}$

149 Asín Palacios, «Ibn al-Sĩd de Badajoz y su "Libro de los cercos"», 54.

150 Es imposible que fuera compuesto en 526/1132, como afirma Ziriklī, dado que Ibn al-Sīd murió en 521/1127.

151 Véase Marín, M., «La actividad intelectual», 529 y 533

152 Apud Tanbih, El Cairo, 1982², 32-3 (estudio introductorio).

153 Véase Ibn al-Abbār, Takmila (ed. al-Harrās), III, n. ${ }^{\circ} 389$.

154 «Ibn al-Sĩd de Badajoz y su "Libro de los cercos"», 50.

155 Véase Marín, M., «La actividad intelectual», 533.

156 Probablemente en su epístola en refutación de Ibn al-Sīd. Véase Ibn al-Abbār, Takmila (ed. al-Harrās), I, n. ${ }^{\circ} 1235$ y II, n. ${ }^{\circ} 68$ e Ibn al-Zubayr, Șila (ed. al-Harrās), V, n. ${ }^{\circ} 192 \mathrm{mim}$. Según al-Marrākušī, lo que enfadaba a Ibn al-Sĩd era que [Ibn Jalașa] le expresara sus defectos de pronunciación y su tartamudeo. Abū Bakr Ibn al- ${ }^{\mathrm{c}}$ Arabī defendió a Ibn Jalașa (Dayl, VI, n. ${ }^{\circ} 894$ ) al igual que Abū ${ }^{\mathrm{C}}$ Abd Allāh Muhammad b. ${ }^{\mathrm{c}} \mathrm{Abd}$ al-'Azīz al-Bāgī, que fue uno de los alfaquíes consejeros a quienes se consultó cuando «Ibn al-Sīd 
atribuyó la verdadera autoría del Iqtiḍāb de Ibn al-Sīd a Aḥmad b. Muḥammad b. Ahmad conocido como Ibn Bullāl (m. ca. 460/1067).

6. Ișläh al-julal fï l-ŷumal. Complemento del $n .^{\circ} 3$ en el que se comentan los errores del Ŷumal de al-Zaŷỹâŷi. La obra de este gramático oriental había levantado un enorme interés en al-Andalus, dedicándosele un buen número de comentarios entre los que destaca el de Ibn al-Sīd ${ }^{157}$. Editada por S. ${ }^{\mathrm{C}} \mathrm{A}$. al-Sa ${ }^{\mathrm{u}} \mathrm{u} \mathrm{d}$, El Cairo, 1980.

7. Al-Ism wa-l-musammà. Epístola sobre el debate acerca de si el nombre es o no lo nombrado. Ibn al-Sīd se alinea con quienes diferencian entre ambas cosas. Esta cuestión es de gran relevancia en la discusión sobre la relación entre los atributos divinos y la unicidad de Dios. La epístola ha sido editada y estudiada por A.J. Elamrani-Jamal 158 .

8. Kitāb fi l-hurūf al-jamsa o Libro sobre las cinco letras, sīn, șād, ḍād, $t \vec{a} \vec{a}^{\prime}$ y dâl cuya articulación fonética se presta a confusiones y cambios ${ }^{159}$. Es posible que haya que conectar la composición de esta obra con la actividad de Ibn al-Sĩd en tanto que almocrí ${ }^{160}$. Una parte de esta voluminosa obra ha sido editada por H. ${ }^{\mathrm{C}}$ A.A. al-Našrātī, El Cairo, 1982. Existe otra edición de Bagdad, 1976.

9. Kitāb al-masā'il wa-l-aŷwiba. Se trata de las siguientes cuestiones: 1) la defensa de al-Waqqaši frente a la acusación de incredulidad, 2) sobre un supuesto error de al-Fārābī en la enumeración de los tres primeros predicamentos del Organon de Aristóteles; esta cuestión incluye a su vez dos preguntas, 3) sobre la inmortalidad del alma, 4) sobre si el mal de ojo es algo real, o no, 5) sobre si es posible convertir el cobre y el plomo en oro y plata respectivamente, un problema muy debatido en la alquimia medieval y 6) debate con Avempace sobre la relación entre gramática y lógica. Algunas de estas epístolas han sido estudiadas y editadas por M. Asín Pa-

dirigió a Ibn Jalașa palabras que le fueron censuradas. Entonces [los alfaquíes] emitieron un dictamen conjunto [según el cual a Ibn al-Sīd debía] aplicársele un correctivo y privársele de la capacidad de dar testimonio» (ahad al-mas'ülìn fĩ mujātabat Abì Muhammad Ibn al-Sid Aba ${ }^{c}$ Abd Alläh Ibn Jalașa bi-alfäz unkirat ${ }^{c}$ alay-hi fa-aftaw ŷami ${ }^{-a n}$ bi-ta'dïbi-hi wa-isqät šahädati-hi) (Takmila, I n. ${ }^{\circ} 1213$ y Dayl, VI n. ${ }^{\circ} 1053$ ). Privar a alguien de la capacidad de actuar como testigo es una medida que puede adoptarse contra el mal comportamiento en materia religiosa, categoría en la que está incluida la mentira. Véase Fierro M., «Religious dissension in al-Andalus: ways of exclusion and inclusion», Al-Qanțara XXII (2001), 463-87, 469.

157 Apud Tanbih, El Cairo, $1982^{2}, 28-9$ (estudio introductorio).

158 «La question du nom et du nommé (al-ism wa-l-musammà) entre la dialectique et la grammaire: à propos d'une épître d'al-Bațalyawsī», Zeitschrift für arabische Linguistik, 15 (1985), 80-93.

159 Véase Asín, M., «Ibn al-Sīd de Badajoz y su «Libro de los cercos»»», 49.

160 Otros almocríes contemporáneos, debido a su especialización, se dedicaron a la composición de obras relacionadas con la fonética y la prosodia. Véase Marín, M., «La actividad intelectual», 535 . 
lacios, A.J. Elamrani-Jamal y E. Tornero ${ }^{161}$. Según M.R. Dāya, existe una edición parcial de Bagdad, por I. al-Sāmarrā'ī 162 .

10. Al-Muqtabas/Muqtabis fi šarh Muwațta' Mālik b. Anas. Según el cadí 'Iyād, era una obra muy extensa y provechosa. Al parecer no se trata de la misma obra editada recientemente con el título Muškilāt Muwatta' Mālik b. Anas por T.b. ${ }^{\mathrm{C}}$ A. Bū Surayh al-Tūnusī, Beirut, 1999. Ésta última es un tratado, bastante sucinto, sobre términos del Muwatta' que, por razones morfológicas o sintácticas, suscitan divergencia de opiniones.

11. Kitāb al-mutallat. En palabras de Asín Palacios, es una obra «sobre los nombres que, derivados de la misma raíz verbal, tienen distinto significado en sus tres tipos, $\mathrm{fa}^{c} l, f \mathrm{f}^{c} l, f u^{c} l$ l). Según Ibn Jallikān, era muy superior a la obra que con el mismo título había compuesto el oriental Qutrub ${ }^{163}$. Existe una edición de S.M. ${ }^{\circ} A$. al-Fartūūīi, Bagdad, 1981.

12. Šarh al-Fașịh, obra del lexicógrafo İa'lab, y Šarh Dīwān al-Mutannabi. El comentario del Fașịh es citado por al-Suyūṭī en al-Faḍd al-Muzhir $f_{i}^{c}$ ulüm al-luga 164 .

13. $\check{S i}^{c} r$ al-Macarrì se trata en realidad de dos obras: a) Šarh Siqt al-zand o explicación de las poesías juveniles compuestas por Abū l- ${ }^{\mathrm{C}} \mathrm{Alä}$

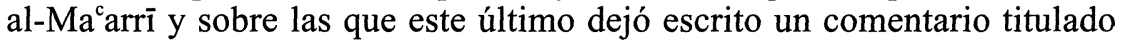
Daw' al-siqț. En opinión de Ibn Jallikān, el de Ibn al-Sīd era mejor que el del propio al-Ma ${ }^{\mathrm{c}}$ arrī. Fue editado bajo el título Šurūh Siqt al-zand por M.

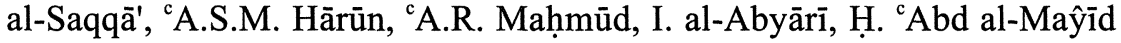
y T. Husayn, El Cairo, 1945; b) Luzūm mà là yalzam: comentario a la colección de poemas de al-Ma ${ }^{c}$ arrī titulada $L u z u \bar{m}$ y que el autor dejó sin interpretar. Corresponden a un momento en la vida del poeta en el que éste se orienta hacia la búsqueda de la verdad, tema en el que Ibn al-Sĩd estaba también muy interesado. Estas dos obras han sido estudiadas por S. Peña 165 .

14. Šarh Dīwān al-Mutannabī. Ibn Jallikān dice haber oído hablar de la existencia de esta obra, pero afirma no haberla visto.

15. Kitäb al-tanbīh 'alà l-sabab al-mūŷìb li-jtiläf al-culamä' $f^{i}{ }^{c} t i-$ qadāti-him wa-ārä'i-him wa-sā'ir agrāḍi-him wa-anhạa'i-him (título que da Ibn Jāqān). La obra es mencionada con otros títulos como: Kitāb sabab ijtilāf al-fuqahā' (cadí 'Iyād y al-Suyūîi); al-Tanbihh calà l-asbāb al-mūŷiba li-jtilāf al-umma (Ibn Baškuwāl); al-Asbāb al-mūŷiba li-jtilâf al-a'imma

161 Asín Palacios, M., «La tesis de la necesidad de la revelación»; Elamrani-Jamal, A.J., «Les rapports de la logique et de la grammaire d'après le Kitāb al-masä'il d'al-Batalyawsī (444-522 = 1052-1127)», Arabica, 27 (1979), 76-89 y Tornero, E., «Cuestiones filosóficas».

162 Véase Tanbih, Damasco, $1987^{2}, 13$.

163 Véase Asín «Ibn al-Sĩd de Badajoz y su "Libro de los cercos"», 48.

${ }^{164}$ El Cairo, 1234/1819, I, 122, apud Bū Surayḥ al-Tūnusī, T..b. ${ }^{c} A .$, Muškilāt Muwatta' Mālik b. Anas, 24 (est. introductorio)

165 Véase Macarri según Batalyawsi. 
(al-Dahabĩ); Kitāb al-tanbīh 'alà l-asbāa al-mūŷiba li-jiläf bayna l-muslimin, etc.

Que se sepa, es la primera monografía andalusí conservada en la que la divergencia doctrinal y dogmática entre los musulmanes es tratada de forma metodológica. De ella existen numerosas copias manuscritas y disponemos de varias ediciones ${ }^{166}$. Sobre su contenido remito a mi artículo «Ibn al-Sīd al-Batalyawsĩ y su obra sobre la discrepancia entre los musulmanes».

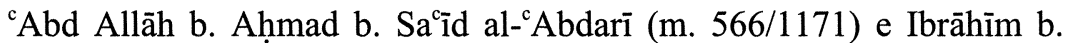
Yūsuf b. Adham Ibñ Qurqūl al-Wahrānī (m. 569/1173) transmitieron el Tanbih al-Andalus; el primero, a su vez, se lo transmitió a Ibn Jayr. En Alejandría, en 523/1129, lo enseñó Abū Isḥāq Ibrāhīm b. Muḥammad al-Mutqin Ibn Ibrāhīm al-Lajmī al-Sabtī (m. después de 570/1174). Al-Kattānī, autor del Fihris al-fahāris, afirma disponer de una copia de la obra que contiene la $i \hat{y} a \bar{z} a$ que Ibn al-Sīd concedió para transmitirla a Ahmad b. 'Uțmān b. Hārūn al-Lajmī en 515/1121. Ibn Qayyim al-Ŷawziyya (m. 751/1350), discípulo de Ibn Taymiyya, cita el Tanbih en su obra sobre discrepancia Šarh al-šăfiya, El Cairo, Maṭba a Hịyāzà, s.d., 31, 35, 75 y 77. También al-Dāmirī conocía el Tanbīh ${ }^{167}$.

16. $\hat{Y} u z^{\prime} f i-h i^{c}$ ilal al-hadit. Esta obra fue transmitida a Ibn Jayr por el maestro tradicionista Abū l-Husayn ${ }^{c} A b d$ al-Malik b. Muhammad b. Hišām, que lo tenía de su autor. Ibn Jayr afirma tenerla escrita al final del Šamátil

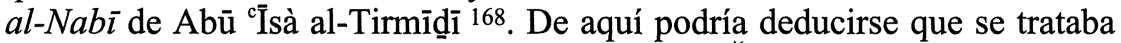
de un comentario a los hadices del mencionado Šamä'il.

17. Tres cartas que suponen un complemento a su epístola sobre el debate con Ibn Bāŷŷa, pues en ellas Ibn al-Sīd insiste en su defensa frente al filósofo zaragozano. Las cartas van dirigidas al visir Abū Muhammad al-Arawšī, al visir Abū Muhammad b. Sufyān y al visir Abū ${ }^{c} \bar{A} m i r$ Ibn al-Kannās, respectivamente ${ }^{169}$.

\section{RESUMEN}

Ibn al-Sīd al-Batalyawsī (Badajoz 444/1052-Valencia 521/1127) es conocido básicamente por su actividad en el campo de la gramática y la lexicografia, y

166 Véase nota 4.

167 Apud Goldziher, I., The Zähiris. Their doctrine and their History (trad. y ed. W. Behn), Leiden, 1971, 78.

168 Véase Ibn Jayr, Fahrasa, I, 249-50 n. ${ }^{\circ} 333$

169 Sobre estos personajes, véase la edición de los textos por Mu'nis, H., «Sab watāìiq ŷadīda can dawlat al-murābiț̄n», RIEEI, 2 (1954), 78-84 y 89-90 (parte árabe). La carta dirigida a Abū Muḥammad b. Sufyān, en la que Ibn al-Sīd respondía a una misiva previa remitida por el mismo personaje, es transmitida también por Ibn Jāqān apud al-Maqqarī, Azhār, III, 142-5. 
por sus incursiones en la filosofía. También destacó en la ciencia del hadiz, interesándose además por cuestiones jurídicas y teológicas. Su obra se ha conservado prácticamente completa. Es valorada positivamente por los biográfos y el interés que ha despertado entre los investigadores modernos ha dado lugar a un buen número de ediciones críticas y estudios. Cuando un investigador se acerca por primera vez a la figura de Ibn al-Sīd comprueba, sin embargo, que los datos disponibles acerca de su vida son escasos y, en ocasiones, de difícil aprovechamiento, y piensa que probablemente a ello se deba la ausencia de un estudio monográfico sobre su trayectoria vital. Con este artículo se pretende llenar ese vacío. Mediante un examen detenido de las fuentes biográficas se pasa revista a los orígenes, formación, campos de actuación, discípulos y obras de Ibn al-Sīd al-Bațalyawsī. Asimismo se intenta fijar la cronología de sus múltiples desplazamientos e indagar en sus motivaciones, para terminar haciendo una valoración de su contribución general a la cultura de al-Andalus. La de Ibn al-Sīd fue una vida a caballo entre dos épocas durante las cuales el poeta y secretario real, que viaja de taifa en taifa en busca de acomodo, tiene que adaptarse, no sin dificultades, a un nuevo contexto político y cultural, tras la conquista almorávid.

\begin{abstract}
Ibn al-Sīd al-Batalyawsī (Badajoz 444/1052-Valencia 521/1127) is known mainly as a grammarian, a lexicographer and, though less so, as a philosopher. He was also a prominent traditionist with interests in jurisprudence and theology, and enjoyed a career as a court-poet and secretary.

Virtually all of his works have survived. They were praised by medieval biographers and have attracted the attention of modern scholars, so that we have quite a number of critical editions and studies of them. By contrast, we have few data on Ibn al-Sid's life, and those few are difficult to use. This is probably why there are so few studies devoted to his career, despite its importance to an understanding of his literary production. This article aims at filling the gap.

I use biographical sources in order to establish Ibn al-Sīd's origins, education, career, pupils and writings. I also attempt to establish where Ibn al-Sīd lived, and when, in different parts of al-Andalus, in the changing political and cultural context following the Almoravid conquest. Finally I offer an assessment of Ibn al-Sìd's general contribution to Andalusī intellectual history.
\end{abstract}

